\title{
INDUSTRIAL OPERATING EXPERIENCE OF THE GTE CERAMIC RECUPERATOR
}

\author{
Subcontract No. 86X22044C \\ Jeffrey M. Gonzalez \\ John L. Ferri \\ GTE Products Corporation \\ Towanda, PA \\ and \\ Wilfred J. Rebello \\ PAR Enterprises, Inc. \\ Fairfax, VA \\ Date Published - June 1990
}

Prepared for the:

DOE Office of Industrial Technologies

ED 0112000

and for the:

OAK RIDGE NATIONAL LABORATORY

Oak Ridge, Tennessee 37831-6285

\section{operated by}

\section{MARTIN MARIETTA ENERGY SYSTEMS, INC.}

for the

U.S. DEPARTMENT OF ENERGY

under Contract DE-ACO5-84OR21400

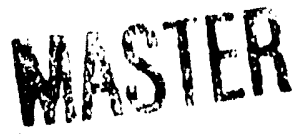

\& 


\section{TABLE OF CONTENTS}

LIST OF FIGURES $\ldots \ldots \ldots \ldots \ldots \ldots \ldots \ldots \ldots$

LIST OF TABLES $\ldots \ldots \ldots \ldots \ldots \ldots \ldots \ldots \ldots \ldots \ldots \ldots$ vii

EXECUTTVE SUMMARY $\ldots \ldots \ldots \ldots \ldots \ldots \ldots \ldots \ldots \ldots \ldots \ldots \ldots$

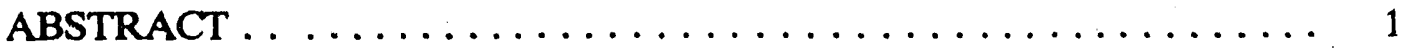

1. INTRODUCTION $\ldots \ldots \ldots \ldots \ldots \ldots \ldots \ldots \ldots \ldots \ldots \ldots \ldots \ldots \ldots \ldots \ldots$

2. INDUSTRIAL APPLICATIONS OF THE GTE RECUPERATOR ... 3

2.1 The GTE Recuperator System Design $\ldots \ldots \ldots \ldots$

2.2 Survey of Industrial Users $\ldots \ldots \ldots \ldots \ldots \ldots$

2.3 Common Problem Areas $\ldots \ldots \ldots \ldots \ldots \ldots \ldots \ldots \ldots$

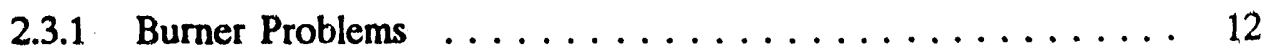

2.3.2 Combustion Control Problems ............. 14

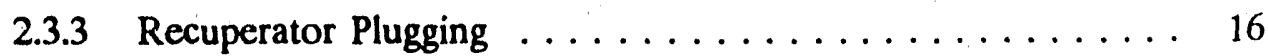

2.3.4 Corrosive Attack ................. 17

3. COMPARATIVE ANALYSIS OF THE RECUPERATOR

APPLICATIONS ..................... 20

3.1 Oil/Gas Consumption for Industrial Process Heat $\ldots \ldots \ldots 20$

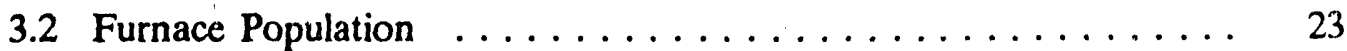

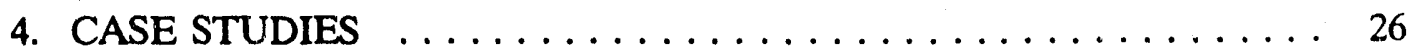

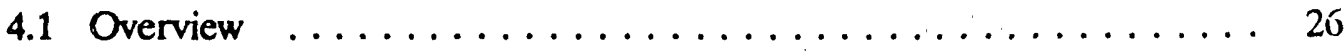

4.1.1 Quality Assurance Measures ............... 27

4.1.2 Post Mortem Analysis Techniques $\ldots \ldots \ldots \ldots 28$

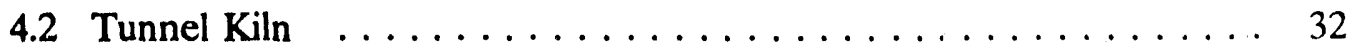

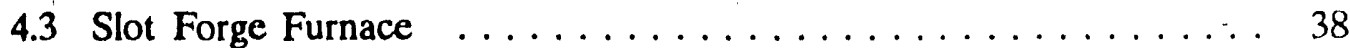

4.4 Lead Wire Annealing Furnace . . . . . . . . . . . . . . . . . . 43

5. CONCLUSIONS AND RECOMMENDATIONS $\ldots \ldots \ldots \ldots \ldots$

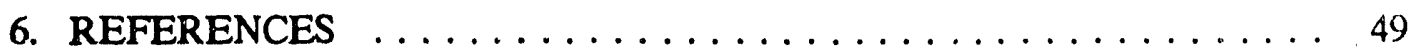

APPENDIX I. List of Recuperator Users Contacted by Phone . . . . . . . 51

APPENDIX II. List of Recuperator Users not Contacted . . . . . . . . . . 59 


\section{LIST OF FIGURES}

Figure $1 \quad$ GTE Ceramic Recuperator Matrix $\ldots \ldots \ldots \ldots \ldots \ldots$

Figure 2 Housed GTE Recuperator with Cutaway Section $\ldots \ldots \ldots \ldots$

Figure 3 Typical Thermal Performance of GTE Ceramic Recuperator ..... 6

Figure 4 GTE Ceramic Recuperator Flow Arrangement . . . . . . . . . . . . 29

Figure 5 R1500 Recuperators on the Bickley Roller

Hearth Tunnel Kiln At Saxonburg Ceramics $\ldots \ldots \ldots 33$

Figure 6 R1500 Recuperator Exhaust Inlet After

15 months of Operation at Saxonburg Ceramics . . . . . . . 34

Figure 7 R1500 Recuperator Exhaust Outlet After

15 months of Operation at Saxonburg Ceramics . . . . . . . 35

Figure 8 Phase Diagram Showing the Cordierite

Phase Field in the Presence of a Sodium Compound . . . . . 37

Figure 9 Side Wall of Dana Slot Forge Reheat Furnace Showing

Burner-Recuperator Location and Gravel Hearth . . . . . . . . 39

Figure $10 \quad$ R1500 Recuperator Exhaust Inlet After 5 months

of Operation on Dana's Slot Forge Reheat Furnace . . . . . . . 40

Figure 11 Air-Side and Exhaust-Side Passage Extracted From the Center

Section of a GTE Recuperator Removed from a Dana

Corporation Slot Forge Reheat Furnace $\ldots \ldots \ldots \ldots \ldots$

Figure 12 Fused Gravel Removed from a Dana Corporation

Slot Forge Reheat Furnace After a 24 -h soak at $2450^{\circ} \mathrm{F} \ldots \ldots 42$

Figure 13 Exhaust Inlet of R1500 Recuperator Removed from Lead

Wire Annealing Furnace at American Spring 'Vire Company . . 44

Figure 14 Exhaust Inlet of R1500 Recuperator Exposed to 200-g of $\mathrm{NaOH}$

at $2500^{\circ} \mathrm{F}$ for $24 \mathrm{~h}$ on GTE's Recuperator Test Furnace . . . . 46 


\section{LIST OF TABLES}

Table 1 List of Recuperator Users Contacted by Phone $\ldots \ldots \ldots \ldots \ldots$

Table 2 List of Recuperator Users Not Contacted . . . . . . . . . . . . . 10

Table 3 GTE Industrial Furnaces/Recuperators $\ldots \ldots \ldots \ldots \ldots \ldots \ldots \ldots$

Table 4 Recuperator Performance by Operating Range . . . . . . . . . . . . 13

Table 5 Recuperator Performance by Size $\ldots \ldots \ldots \ldots \ldots \ldots \ldots$

Table 6 Comparative Analysis of the GTE Ceramic

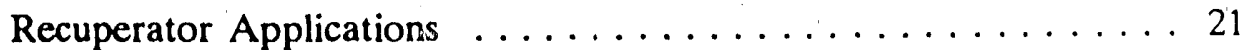

Table 7 Oil \& Gas Consumption for Direct

Process Heat for GTE Targeted Industries . . . . . . . . . 22

Table 8 Furnace Energy Consumption/Population . . . . . . . . . . . . . 24

Table 9 GTE Recuperator Nominal Air Flow Ratings . . . . . . . . . . . . 28

Table 10 Elements Sought and Detection Limits During

Spectrographic Qualitative Analysis $\ldots \ldots \ldots \ldots \ldots \ldots$

Table 11 Spectrographic Qualitative Analysis of Samples

from Saxonburg Ceramics $\ldots \ldots \ldots \ldots \ldots \ldots$

Table 12 Spectrographic Qualitative Analysis of Fired and

Unfired Gravel from Dana's Slot Forge Furnace . . . . . . . . . 42

Table 13 Spectrographic Qualitative Analysis of Sample from

American Spring Wire Company $\ldots \ldots \ldots \ldots \ldots$ 


\section{EXECUTIVE SUMMARY}

GTE Products Corporation, under a jointly funded program with the U.S. Department of Energy (DOE), developed a compact ceramic high temperature recuperator that could recover heat from relatively clean exhaust gases at temperatures up to of $2500^{\circ} \mathrm{F}$. The DOE program was very successful in that it allowed GTE to improve the technical and economic characteristics of the recuperator and stimulate industrial acceptance of the recuperator as an energysaving technology.

The success of the DOE Program was measured by the fact that from January 1981 to December 1984, 561 recuperators were installed by GTE on new or retrofitted furnaces. One objective of this contract was to conduct a telephone survey of the industrial plants that use the recuperator to determine their operating experience, present status, and common problems, and thus to complete the historical picture.

The ceramic matrix material is made of cordierite, a magnesium aluminum silicate, in 10in.cubes, 12-in.cubes, and 12- x 12- x 18-in. units that are rated at 0.6,1.0, and 1.5 million $\mathrm{Bti} / \mathrm{h}$ respectively. The exhaust gases from the furnace flow straight through the recuperator, while the air to be heated makes three passes. This arrangement allows air to be heated to $1300^{\circ} \mathrm{F}$ with exhaust gas temperatures of $2400^{\circ} \mathrm{F}$. The three pass arrangement is counterflow with respect to the exhaust flow path. The design helps minimize temperature-induced stresses in the cordierite material, thus improving the reliability of the unit.

The thrust of the marketing effort was in the metal processing industries. This focus appears to be correct in view of the energy consumption and number of furnaces in these industries. The durability of the recuperators is indicated by their survival rate. Among 561 units installed on 165 new or retrofitted furnaces in 89 plants, 405 units (72\%) were operating after 4 years. There are 117 units $(21 \%)$ that are not in use either because of failure, poor business climate, or plant shutdown. The combined energy saving of the present operating units is estimated to be about $0.5 \times 10^{12} \mathrm{Btu} /$ year.

The reliability of the recuperated furnace is high in the lower temperature applications. Most of the recuperators $(87 \%)$ installed on furnaces operating at $2000^{\circ} \mathrm{F}$ and below were operational through June 1988 , while only $57 \%$ were being used on furnaces operating above $2000^{\circ} \mathrm{F}$. Regarding recuperator size, the smallest unit seems to be more reliable. Of the three sizes of recuperators installed, $89 \%$ of the small 10 -in.cubes, $72 \%$ of the intermediate 12 in.cubes and only $56 \%$ of the large units were operational. Possibly the large units are more severely stressed during operation or flaws may develop during the fabrication process.

The initial problems with hot air burners and combustion controls were solved by GTE 
and the burner manufacturers. The current problems are recuperator plugging and corrosive attack by alkali compounds, both of which depend on the specific application. In most cases, plugged recuperators could be cleaned with an air lance during normal shutdown and reused. The alkali compounds appear to form lower temperature eutectics with the cordierite material, and if the furnace operating temperatures exceeded the softening point of the eutectic, failure occurred.

Soures of alkali compounds are fluxes used in aluminum remelt furnaces or pottery kilns, topping compounds used on steel ingots, and effluents from organic materials (trace concentrations) generated over extended periods of operation (16,000 hours). This study confirmed the effect of temperature on the life cycle of the recuperator. At temperatures above $2150^{\circ} \mathrm{F}$ life cycles can be reduced to weeks if the concentration of a reactive contaminant is high. A reduction of the alkali concentration (process modification), and/or reduction of the exhaust inlet temperature below $2100^{\circ} \mathrm{F}$ is required for successful application of the GTE ceramic recuperator. Injection of a sufficient quantity of ambient air into the exhaust gas stream before it enters the recuperator is one method utilized to maximize the life cycle of the ceramic. The reduced exhaust inlet temperature reduces the reaction rate of the contaminant. The recuperator efficiency is reduced only nominally. The decrease in exhaust inlet temperature and the increase in mass flow rate balance each other, resulting in negligible loss in preheat air temperature. The exhaust gas-flow inducement device (eductor) can generally accommodate the increased volume of exhaust gases, usually less than $10 \%$. A combustion system designer must include ceramic matrix replacement costs based upon reduced life cycles into a projects economic feasibility analysis. Since there is no easy solution to alkali attack, applications generating large amounts of alkali should be avoided.

About 48,000 furnaces were identified that were similar to those in the 89 plants where the recuperators were installed. Based on the industrial users experience with this recuperator, the following industries are potential markets: metal heat treating, aluminum foundries, steel mills, steel forging, and structural clay products. Because of contaminated exhaust gas streams, the following applications should be avoided: tunnel kilns in the pottery and related industries, ladle preheaters in the ferrous and nonferrous industries, remelt and kettle furnaces in the secondary nonferrous industries and reheat/forge furnaces processing steel ingots with topping compounds. 


\begin{abstract}
GTE Products Corporation, under a jointly funded program with the U.S. Department of Energy (DOE), developed a compact ceramic high temperature recuperator that could recover heat from relatively clean exhaust gases at temperatures up to of $2500^{\circ} \mathrm{F}$. The DOE program was very successful in that it allowed GTE to improve the technical and economic characteristics of the recuperator and stimulate industrial acceptance of the recuperator as an energysaving technology. The success of the DOE Program was measured by the fact that from January 1981 to December 1984, 561 recuperators were installed by GTE on new or retrofitted furnaces. One objective of this contract was to conduct a telephone survey of the industrial plants that use the recuperator to determine their operating experience, present status, and common problems, and thus to complete the historical picture. Additionally, recuperators were returned to GTE after operating on industrial furnaces, and a "post mortem" analysis was undertaken with a goal of identifying the potential reason(s) for premature failure of the ceramic matrix. When contamination of the matrix was evident, historical data and spectrographic analysis were used to identify the type of contaminant, and its source. This effort has shown the type of degradation that occurs and has identified.system design techniques that can be used to maximize the ceramic recuperator life cycle.
\end{abstract}

\title{
1. INTRODUCTION
}

GTE Products Corporation began development of ceramic heat exchangers in 1973. This activity resulted in a high-temperature compact cross-flow recuperator made of cordierite which functions well in relatively clean exhaust gases at temperatures up to $2500^{\circ} \mathrm{F}$. Part of the development work, which was jointly funded by DOE and GTE under Contract EX-76-C01-2612 began in October 1976. A final report ${ }^{1}$ published by DOE in August 1980 described development and field testing.

In August 1980, the DOE and GTE started a cooperative program titled a Technology Acceleration Program for High Temperature Recuperators (TAPHTR) ${ }^{2}$. The primary goals of the cooperative agreement were to test, install, and collect baseline and operating data for 175 industrial applications of the high-temperature recuperator. The specific tasks of this program were to accurately assess the industrial high-temperature process requirements; to improve the technical and economic characteristics of the recuperator; to stimulate the industrial acceptance of the recuperator for waste heat recovery; and, by saving energy and increasing productivity, to further DOE's Office of Industrial Programs industrial conservation efforts.

During the TAPHTR program, 175 recuperators were installed on 38 furnaces in 30 
industrial plants. With the exception of six newly designed furnaces, the furnaces were retrofitted with recuperators. These furnaces were operated at temperatures ranging from $1600^{\circ} \mathrm{F}$ to $2500^{\circ} \mathrm{F}$ and air preheat temperatures of $700^{\circ} \mathrm{F}$ to $1300^{\circ} \mathrm{F}$ were obtained. Four furnaces were fired by \# 2 fuel oil, one by $\# 4$ fuel oil, and the others with natural gas. Preheated air burners were manufactured by Eclipse Inc., Hauck Manufacturing Company, North American Manufacturing Co., and Selas Corporation. The combustion control systems which regulate temperature and fuel:air ratio were modified to accommodate the preheated air from the recuperator. Both pneumatic pressure and mass-flow controls as well as electronic control systems were used.

The TAPHTR program was successful in that it provided the following benefits to the host sites:

- Fuel savings of $12 \%$ to $61 \%$ made the retrofits economically attractive.

- Productivity increases resulted because of higher product throughputs, lower furnace reheat times, and, in the case of batch furnaces, more cycles per shift.

- In some cases, materials savings resulted from decreased scale formation.

The TAPHTR program also revealed system problems, some of which were solved during the course of the program or soon after. These were as follows.

- Inherent leakage around the seals could be tolcrated provided fuel-rich conditions did not exist in the furnace.

- The initial hot air burners deposited carbon and had flame instability, hut these were later corrected by the burner companies.

- Combustion controls on the cold-air side were not adequate to prevent excess gas conditions in the furnace. This was corrected after the TAPHTR program by development of a simple but novel hot-air side control system.

- In some cases, plugging of the compact recuperator passages necessitated the use of an on-line or periodic air-lance cleaning system.

- Some furnaces produce alkali or lead-based materials that can degrade the 
magnesium aluminum silicate recuperator at temperatures above $2100^{\circ} \mathrm{F}$. Many furnaces, originally categorized as producing clean exhaust, volatilize these materials as a result of the specific process or the furnace design. Degradation of the ceramic can often be eliminated or reduced by careful system design; however, experience has shown that subtle process or system design changes san produce greatly different exhaust gas constituents.

- A recuperator capable of withstanding the attack of common contaminants (alkali compounds) could accelerate the market acceptability of the ceramic heat exchanger, because a more confident estimate of life cycle could be offered for various applications.

The success of the DOE/GTE TAPHTR program is indicated by the fact that between January 1981, when the first DOE installation was started, and December 1984, about 560 recuperators were sold by GTE on new or retrofitted furnaces. Since the start of the DOE TAPHTR program, about 1200 recuperators were sold as either new or replacement units. A telephone survey was made of the industrial plants that installed the ceramic recuperator to determine their operating experience, present status, and common problems, and thus to complete the historical perspective of the recuperator. This report details the results of the telephone survey of the industrial users and provides some comparative analysis of the ceramic recuperator applications.

\section{INDUSTRIAL APPLICATIONS OF THE GTE RECUPERATOR}

\subsection{THE GTE RECUPERATOR SYSTEM DESIGN}

Ceramic recuperators are manufactured in three sizes: a $10 \times 10 \times 10 \mathrm{in}$. ceramic core with a recommended capacity of 0.6 million Biu/h, a $12 \times 12 \times 12$ in. core with a capacity of 1.0 million Btu/h and a $12 \times 12 \times 18$ in. core with a recommended capacity of 1.5 million Btu/h. The ceramic cores are constructed of cordierite, a magnesium aluminum silicate (MAS), which was selected because of ease of fabrication, relatively low thermal expansion, good thermal shock resistance, and certain corrosion-resistant characteristics. The recuperator is manufactured by bonding extruded MAS ribbed-sheets with a cordierite ceramic bonding material. The sheets and ribs are arranged to form a cross-flow heat exchanger (Figure 1). The ceramic core unit and resilient refractory seal are contained in a metallic housing. The unit is under a 
slight compression from a spring assembly. A key feature of current recuperators is that the preheat air makes three passes in the recuperator while the exhaust gas passes through once. The air side passes are made possible by baffles in the metal housing (Figure 2). The areas of each pass are selected to optimize the heat tra' sfer for a given pressure drop ${ }^{3}$. Figure 3 shows the typical performance of a model R1000 (12 x $12 \times 12 \mathrm{in}$.) recuperator. The triple-pass recuperator provides higher preheated air temperatures than the earlier single-pass model. An added advantage of the triple-pass recuperator is that the maximum temperature difference between the exhaust gases and the preheated air is reduced. Temperature-induced stresses are therefore lower, thus increasing the reliability of the recuperator.

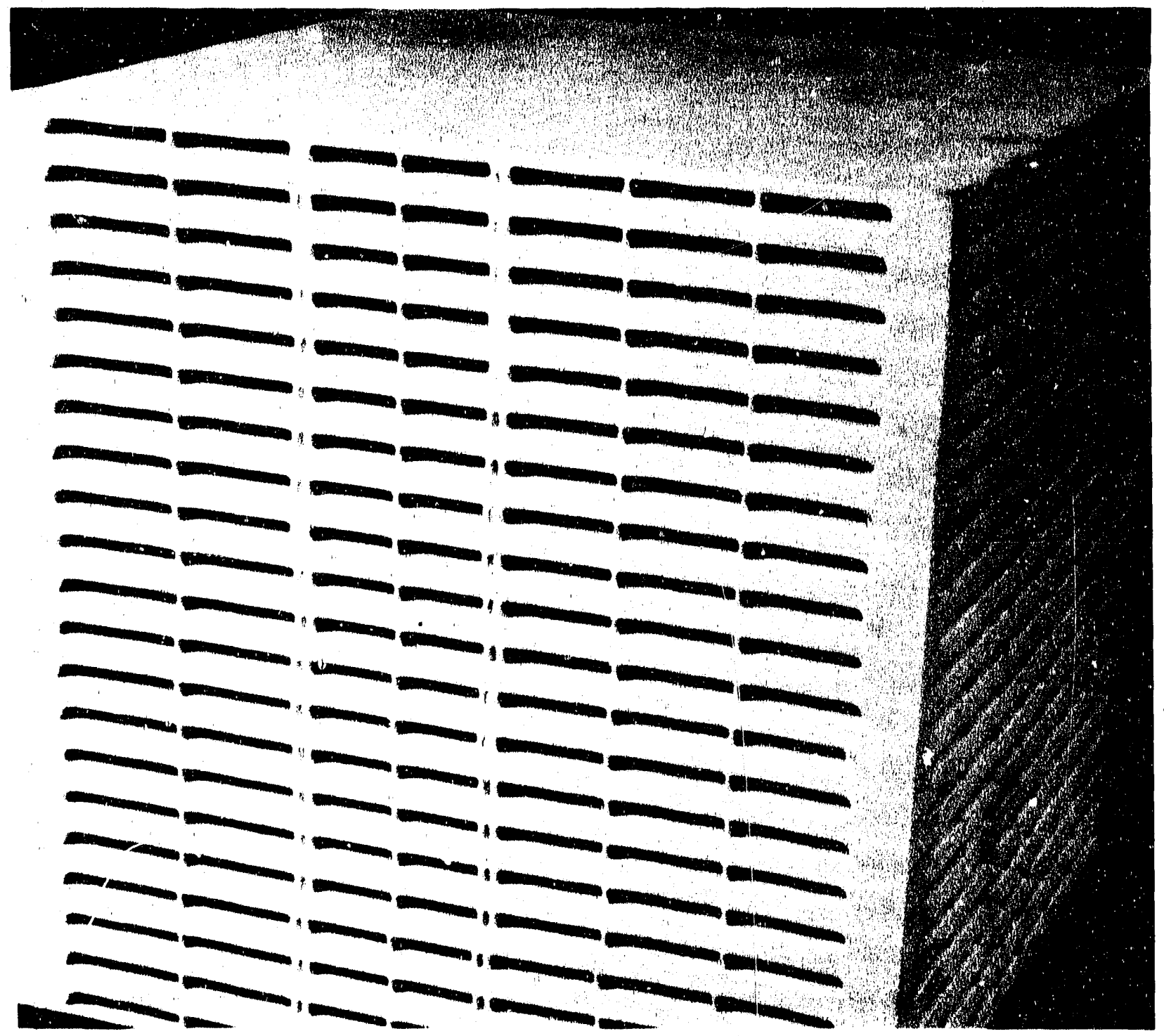

Figure 1

GTE Ceramic Recuperator Matrix 


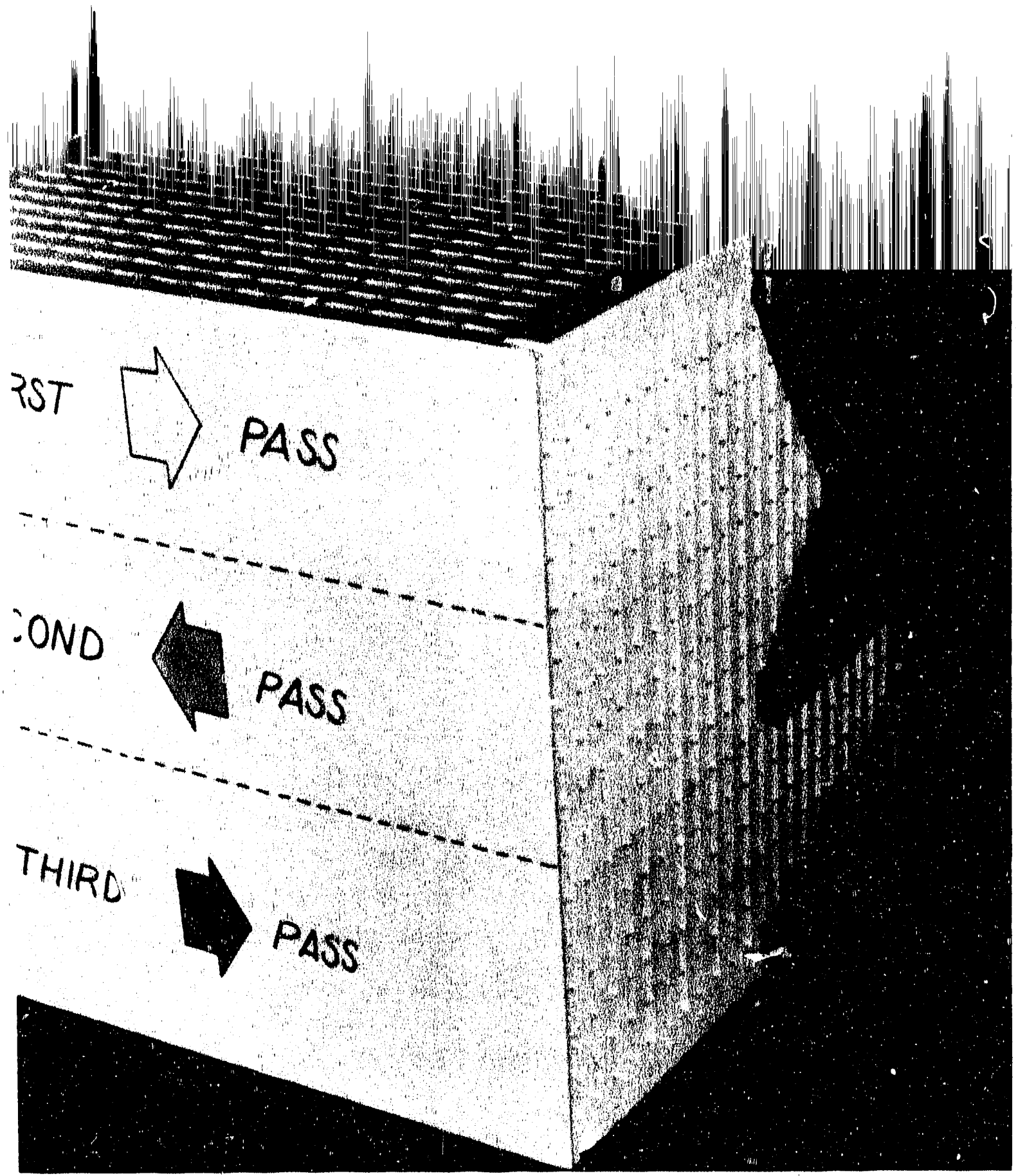

Figure 2

Housed GTE Recuperator with Cutaway Section 


\section{GTE}

\section{TPXA}

- Product Code: 8163228

- Air Hole Slze: $.125^{\prime \prime} \times .680^{\prime \prime}$

- Exhaust Hole Size: $.200^{\prime \prime} \times .680^{\prime \prime}$

- Flow Ratio $=0.917 \pm 5 \%=\frac{\text { Alr Flow }}{\text { Exhaust FTow }}$
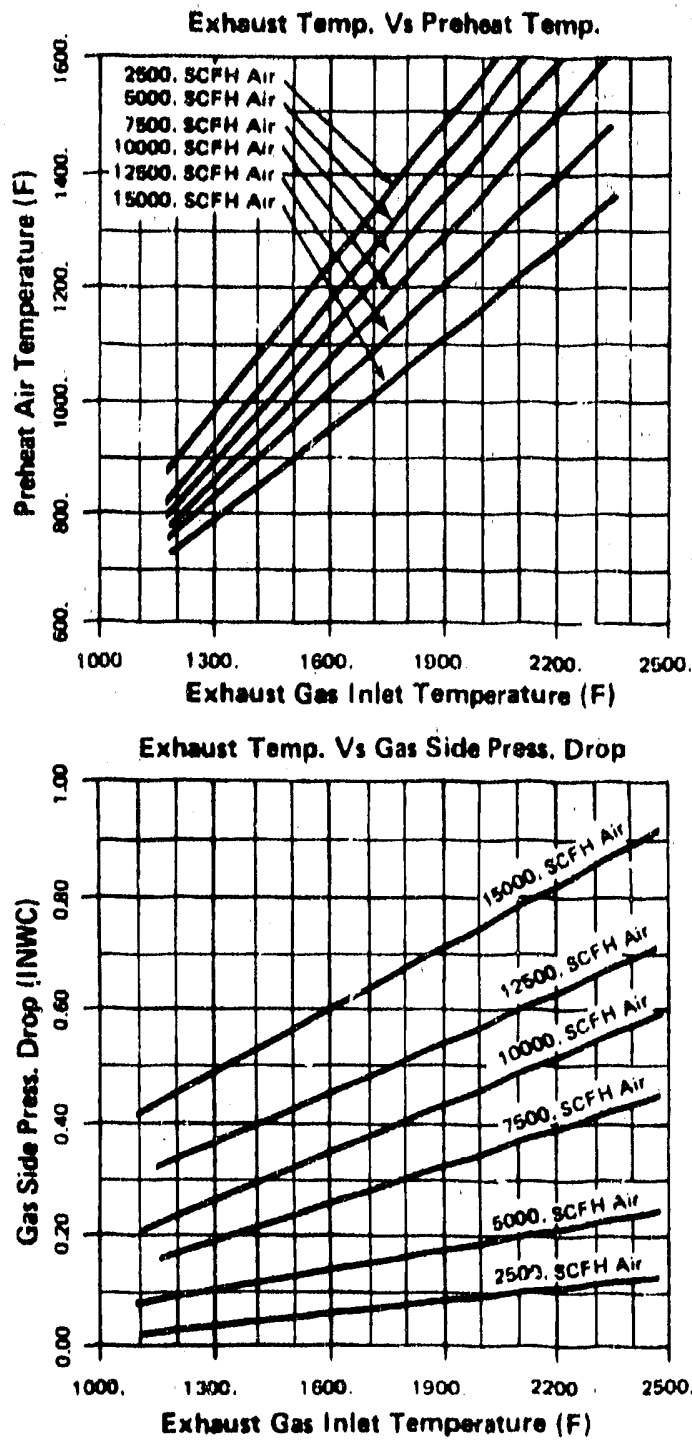

Exhaust Gas Inlet Temporature (F)
Exempla:

$11 / \mathrm{mm}$ BTU Burner Using $10 \%$ excens air

Air Flow a 16500 SCFH

Gas Flow - 1500 SCFH

Exheust Flow - 10000 SCFH

Prineated Air Temp. at 20000F Exhaun - 10500 F

Pressure Drop Exhewst .77" $\mathrm{H}_{2} \mathrm{O}$ Column

Pressure Drop Alr 20" $\mathrm{H}_{2} \mathrm{O}$ Column
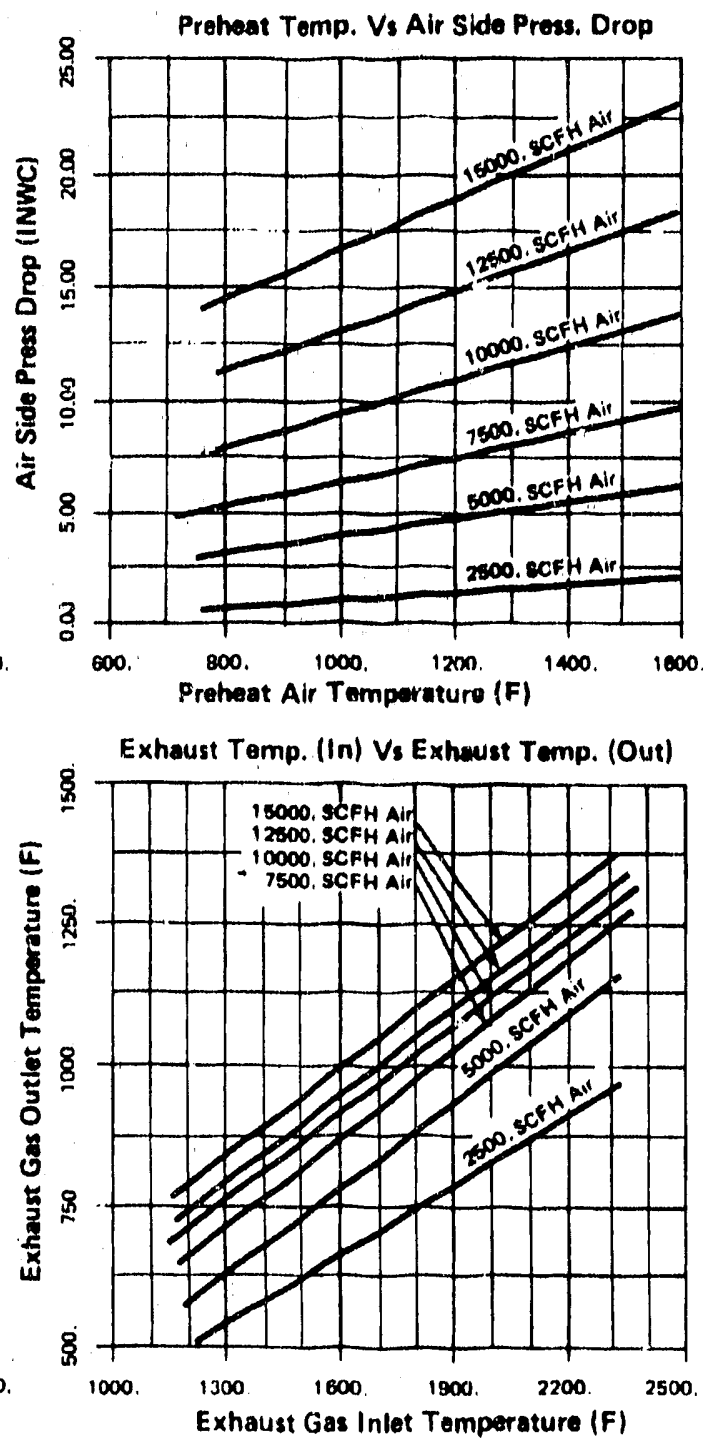

SYLVANIA Chemicals

Figure 3

Typical Thiermal Performance of GTE Ceramic Recuperator 
Since the TAPHTR program ended in 1982, the techniques for production, firing, and encasement of the ceramic cube in the metallic housing have been improved, which have resulted in a more reliable product. Another improvement in the recuperator system is related to the method of controlling the air:fuel ratio to the burner. The common methods of mass flow control, if applied to the cold-air side, do not compensate for changes in recuperator leakage and, if applied to the $\mathrm{r} t \mathrm{t}$ preheated air side, do not account for variations in the preheated air temperature. In case the recuperator leaks, the cold-side control would not correct the air:fuel ratio and the furnace could run fuel rich, if the leakage was large. In the case of controls applied to the preheated air, as the preheated air temperature increases, the air:fuel ratio decreases and fuel rich conditions could result depending on the air:fuel ratio established at system calibration. In the patented GTE temperature cornpensator ${ }^{4}$, a bimetallic strip in the preheated air stream compensates the prescure signal which contrcls the fuel flow, thus preventing a fuelrich condition. This simple, relatively inexpensive device is now of fered as part of the standard recuperator package.

\subsection{SURVEY OF INDUSTRIAL USERS}

The survey of industrial users of the GTE ceramic recuperator was based on al listing of companies in the United States and Canada provided by GTE. Seventy-two companies were contacted by phone and the present status as well as furnace/recuperator information were noted. These are presented in Table 1 and includes summary remarks regarding the industrial users experience and problems encountered. Seventeen industrial users were not traced either because they were not in business or had been acquired by another company. These 17 companies had no known telephone numbers and are listed in Table 2 . The information listed in Table 2 is based on GTE records and contacts. In some cases the recuperators were scrapped prior to the companies close of business and have been noted as such. In the remaining cases the curre it status is unknown.

From the total of 89 industrial companies in the United States and Canada, 561 recuperators were installed on 165 new or retrofitted furnaces. Hot Work in the United Kingdom purchased 53 recuperators for installation, but their status is not known. In addition, 35 recuperators were purchased by various Japanese companies and their status is likewise not known at this time. A listing of the furnace types and number of recuperators are presented in Table 3 . Of the total 571 new recuperators, 415 or $72 \%$ are still operating and 117 are not in use at present either because of failure, poor performance, or plant shutdown. The box-type furnace used either 
Table 1

List of Recuperator Users Contacted by Phone

\begin{tabular}{|c|c|c|c|c|c|}
\hline COMPANY & FURNACE TYPE & TEMP & REC. SIZE & REC \# & PREHEAT \\
\hline Ajax X-Ray & Potmelter & 2150 & 0.6 & 1 & 1100 \\
\hline Ajax X-Ray & Potmelter & 2200 & 0.6 & 1 & 1150 \\
\hline ALCAN & Ladle Preheater & 1800 & 1.0 & 1 & 1000 \\
\hline $\begin{array}{l}\text { Alfred Heller Heat Treating Co. } \\
\text { AmCast Ind.Corp. (Dayton Malleable) }\end{array}$ & Muffle Heat Treat & 2100 & 1.5 & 2 & \\
\hline American Spring Wire & Lead Potmelter & 2300 & 1.5 & 2 & 1050 \\
\hline B\&R Industries Inc. & Aluminum Potmelter & 2000 & 0.6 & 1 & 750 \\
\hline Bay City Forge & Box Forge & 2250 & 1.5 & 8 & 1200 \\
\hline Berkley Forge & Slot forge & 2400 & 1.5 & 2 & \\
\hline Brampton Foundry & Potmelter & 2300 & 0.6 & 1 & 600 \\
\hline Brown Engineering & Fume Incin & 1200 & 1.5 & 1 & 200 \\
\hline Bucyrus Erie Co. & Heat treat & 1800 & 0.6 & 12 & 1000 \\
\hline Buffalo Metal Casting & Aluminum Potmelter & 2200 & 1.0 & 1 & 1000 \\
\hline Callen Mfg. Corp. & Al. remelt furnace & 2200 & 1.5 & 2 & 1000 \\
\hline Carpenter Die & Pot Melters & 2000 & 0.6 & 8 & 1000 \\
\hline CER'TECH Inc. & Periodic Kilns & 2200 & 0.6 & 2 & 1000 \\
\hline Compton Forge & Box forge & 2250 & 1.5 & 4 & \\
\hline Conroe Forge \& Mfg. & Pusher Fumace & 2200 & 1.5 & 4 & 1100 \\
\hline Coulter Steel \& Forge Co. & Box Forge & 2200 & 0.6 & 2 & 1150 \\
\hline Crucible Steel & Box Reheat & 2200 & 1.5 & 2 & 1050 \\
\hline Eastem Alloys & Kettle Fumace & 2200 & 1.5 & 2 & \\
\hline Empire Steel Casting & Anneal. & 2000 & 1.0 & 2 & 1000 \\
\hline Endicott Forgine \& Mfg. & Slot Forge & 2350 & 1.5 & 4 & 1300 \\
\hline Finkl \& Sons Inc. & Box Forge & 2300 & 1.5 & 2 & 1200 \\
\hline GTE & 9 Rotary Calcines & 1800 & 1.5 & 6 & 1000 \\
\hline GTE & & & 0.6 & 23 & \\
\hline GTE & 9 Tube Fumaces & 1500 & 1.5 & 8 & 1200 \\
\hline GTE & & & 1.0 & 23 & 800 \\
\hline GTE & 4 Tube Fumaces & 2100 & 0.6 & 40 & 800 \\
\hline Gudgeon Bros. & Aluminum Potmelter & 2200 & 0.6 & 1 & 900 \\
\hline Gulfco & Boxforge & 2450 & 1.5 & 8 & 1150 \\
\hline Gulfco & Boxforge & 2450 & 1.5 & 8 & 1150 \\
\hline Gulfco & Boxforge & 2450 & 1.5 & 6 & 1150 \\
\hline Hammond \& Irving & Box Heat Treat & 2200 & 1.5 & 4 & 1100 \\
\hline Hammond \& Irving & Box Heat Treat & 2200 & 1.5 & 2 & 1100 \\
\hline Hamischfeger Co. & Pusher Furnace & 2000 & 1.5 & 4 & 1150 \\
\hline Hayes Dana Co. & Carbottom & 2300 & 1.5 & 8 & 1200 \\
\hline Hayes Dana Co. & Slot Forge & 2300 & 1.5 & 2 & 1200 \\
\hline Howmedica Inc. & Pusher Type Mold Heater & 2000 & 1.5 & 2 & 800 \\
\hline Howmet Turbine Co. & Pusher Reheat & 2200 & 1.5 & 1 & $i 240$ \\
\hline Howmet Turbine Co. & & & 1.0 & 2 & \\
\hline Howmet Turbine Co. & Fum. $\$ 2$ & 2250 & 1.5 & 1 & 1200 \\
\hline Howmet Turbine Co. & & & 1.0 & 2 & \\
\hline Howmet Turbine & Pusher Die Reheat \#1 & 2300 & 1.5 & 1 & 1190 \\
\hline Howmet Turbine & & & 1.0 & 2 & \\
\hline Howmet Turbine & Furn.\# 2 & 2300 & 1.5 & $i$ & 1180 \\
\hline Howmet Turbine & & & 1.0 & 2 & \\
\hline Kentucky Forge & Slot forge & 2500 & 0.6 & 2 & 1200 \\
\hline Kleen Air & Ladle Heat & 2200 & 1.5 & 1 & 1100 \\
\hline Krone Diecasting Co. & Reverb. Fumace & 2200 & 1.0 & & \\
\hline Ladish Company & Box Heat $\mathrm{T}_{2}$ & 1800 & 0.6 & 8 & 850 \\
\hline Lebanon Steel Foundry & Carbottom Heat Treat & 1800 & 1.5 & 6 & 850 \\
\hline Littler Diecast Corp. & Al. Pot Holding Furnace & 2000 & 1.0 & 1 & 800 \\
\hline Maynard Steel Casting & Car bottom Heat Treat & 1650 & 1.0 & 12 & 850 \\
\hline McInnes Steel & Boxforge & 2250 & 1.5 & 4 & 1210 \\
\hline McWilliams Forge & Box Forge & 2100 & 1.5 & 3 & 1160 \\
\hline
\end{tabular}




\section{Table 1}

\section{List of Recuperator Users Contacted by Phone}

\begin{tabular}{|c|c|c|c|c|c|}
\hline COMPANY & FURNACE TYPE & TEMP & REC. SIZE & REC \# & PREHEAT \\
\hline McWilliams Forge & Rotary Hearth & 2300 & 1.5 & 8 & 1200 \\
\hline Mercury Marine & Al. Reverb & 2000 & 1.5 & 2 & 1000 \\
\hline Milwaukee Forge & Carbottom Annealing & 1550 & 1.0 & 10 & 800 \\
\hline Missouri Steel Castings & & & 1.0 & 4 & \\
\hline Monroe Forge & Box Forge & 2150 & 1.5 & 2 & 1220 \\
\hline Monroe Forge & Box Forge & 2150 & 0.6 & 2 & 1050 \\
\hline Monroe Forge & Box Forge & 2150 & 1.0 & 2 & 1000 \\
\hline Monroe Forge & Box Forge & 2150 & 1.0 & 2 & 1000 \\
\hline National Forge & Carbottom Heat Treat & 2350 & 1.5 & 8 & 1175 \\
\hline Norfolk \& Westem Rly. Co. & Carbottom Heat Treat & 1800 & 1.0 & 7 & 1000 \\
\hline North Vernon Forge & Slot forge & 2500 & 1.5 & 2 & 1200 \\
\hline Oregon Metallurigical & Slot Forge & 2500 & 1.5 & 2 & 1200 \\
\hline Oregon Metallurigical & Heat Treat & 2200 & 0.6 & 14 & 1100 \\
\hline Oregon Metallurigical & Box Forge & 2200 & 0.6 & 12 & 1100 \\
\hline Pfizer Company & Vacuum Retort & 2200 & 0.6 & 5 & 1150 \\
\hline Pfizer Company & Vacuum Retort & 2200 & 0.6 & 5 & 1150 \\
\hline Pfizer Company & Vacuum Retort & 2200 & 0.6 & 5 & 1150 \\
\hline Pfizer Company & & 2200 & 0.6 & 5 & 1150 \\
\hline Pfizer Company & Indirect Fired Calciners (8) & 1900 & 1.5 & 32 & 1200 \\
\hline Pfizer Company & Muffle & 1800 & 1.0 & 2 & 600 \\
\hline Pfizer Company & Annealing & 2100 & 0.6 & 6 & 800 \\
\hline Pfizer Company & Annealing & 2100 & 0.6 & 6 & 800 \\
\hline Pratt \& Whitney & Box Heat Treat & 2100 & 0.6 & 5 & 1150 \\
\hline Precision Cast Parts Corp. & Mold Preheating (10) & 1900 & 1.5 & 20 & 900 \\
\hline Puget Sound & & 2400 & 1.5 & 1 & 1200 \\
\hline Salt Fleet Aluminum Co. & Aluminum Pot Melters & 2000 & 0.6 & 1 & 900 \\
\hline Salt Fleet Aluninum Co. & & 2000 & 0.6 & 1 & 900 \\
\hline Saxonburg Ceramics Inc. & Rolls/Kiln & 1800 & 1.5 & 2 & 1000 \\
\hline Schmitt Forge & Slot Forge & 2250 & 1.5 & 2 & 1120 \\
\hline Scott Forge & Box Forge & 2350 & 1.5 & 2 & 1100 \\
\hline Sherwood Medical & Heat Treat & 1890 & 1.5 & 2 & 1000 \\
\hline Sherwood Medical & & & 1.5 & 2 & 1000 \\
\hline Special Metals & Heat Treat & 1800 & 1.5 & 6 & 1100 \\
\hline Special Metals & Reheat & 2000 & 1.5 & 4 & 1200 \\
\hline Special Metals & Batch Annealing Furnace & 1800 & 1.5 & 2 & 1100 \\
\hline Special Metals & Forge & 2350 & 1.0 & 10 & 1100 \\
\hline Standard Steel Co. & Forge Reheat & 2300 & 1.5 & 6 & 1100 \\
\hline Stanley Tools & Slot forge & 2200 & 1.0 & 1 & 1000 \\
\hline Standey Works & Lead Pot Melter & 2050 & 0.6 & 8 & 950 \\
\hline Timet Corp. & Box Forge & 1800 & 0.6 & 8 & 950 \\
\hline Trent Tube Co. & Annealing Furnace & 1800 & 1.0 & 3 & \\
\hline TRW form Stanley Spring & Slot forge & 1900 & 0.6 & 4 & \\
\hline Viking Metallurgical Corp. & Box Forge & 2250 & 1.0 & 2 & 1200 \\
\hline Viking Metallurgical Corp. & Box Forge & 2250 & 1.0 & 2 & 1200 \\
\hline Viking Metallurgical Corp. & Box Forge & 2250 & 1.0 & 4 & 1200 \\
\hline Viking Metallurgica Corp. & Box Forge & 2250 & 1.0 & 5 & 1200 \\
\hline Willard Industries Lic. & Solder Pots & 1800 & 0.6 & 3 & 600 \\
\hline Willard Industries Inc. & $(5$ total $)$ & & 0.6 & 1 & 700 \\
\hline Willard Industries Inc. & & & 0.6 & 1 & 800 \\
\hline$X$-TEK Inc. & Retort Pit & 1800 & 0.6 & 12 & 1000 \\
\hline $\mathrm{X}$-TEK Inc. & Retort Pit & & 0.6 & 12 & 1000 \\
\hline $\mathrm{X}$-TEK Inc. & Retort Pit & & 0.6 & 12 & 1000 \\
\hline
\end{tabular}


Table 2

List of Recuperator Users Not Contacted

\begin{tabular}{|c|c|c|c|c|c|}
\hline COMPANY & TYPE & $\begin{array}{l}\text { TEMPERATURE } \\
\mathrm{F} \\
\end{array}$ & $\begin{array}{c}\text { SIZE } \\
\text { MMBTU/HR } \\
\end{array}$ & $\begin{array}{c}\text { NUMBER OF } \\
\text { RECUPERATOKS }\end{array}$ & $\begin{array}{c}\text { TEMP } \\
\mathrm{F}\end{array}$ \\
\hline Alteck & Box Reheat & 2200 & 1.5 & 6 & 1200 \\
\hline AMAX Speciality & Box Forge & 2300 & 1.0 & 5 & 1200 \\
\hline Bethlehem Steel & Rotary Forge & 2350 & 1.5 & 8 & 1250 \\
\hline Cape Ann Forge & Box Forge & 2350 & 1.5 & 4 & 1250 \\
\hline Cedarbmok Eng. & Al Reverb. & 2200 & 1.5 & 1 & 1100 \\
\hline Cooper Ind. & Slot Forge & 2450 & 1.5 & 2 & 1200 \\
\hline Crescent Tool & Slot Forge & 2400 & 1.5 & 2 & 1250 \\
\hline DANA & Slot Forge & 2400 & 1.5 & 12 & 1250 \\
\hline ICE & & 1800 & 0.6 & 1 & \\
\hline Inland Steel & Annealing & 1800 & 0.6 & 1 & \\
\hline Janney Cylinder & & & 1.0 & 2 & \\
\hline Metamold & Reverb. & 1400 & 1.0 & 2 & 800 \\
\hline National Lead & Lead Melter & 1800 & 1.5 & 1 & 1000 \\
\hline O'Hara & Lead Melter & 1800 & 1.5 & 2 & 1000 \\
\hline Pyronics & Forge & 2200 & 1.0 & 1 & \\
\hline Rockwell & Slot Forge & 2350 & 0.6 & 2 & 1000 \\
\hline WFI & Box Forge (2) & 2200 & 0.6 & 3 & \\
\hline WFI & Heat Treat (2) & 1950 & 1.5 & 3 & \\
\hline England & & & & 43 & \\
\hline Japan & & & & 35 & \\
\hline
\end{tabular}


Table 3

GTE Industrial Furnaces/Recuperators

\begin{tabular}{|c|c|c|c|c|c|}
\hline \multirow{2}{*}{\multicolumn{2}{|c|}{ Furnace Type }} & \multirow[b]{2}{*}{$\begin{array}{l}\text { Number of } \\
\text { Furnaces }\end{array}$} & \multicolumn{3}{|c|}{ Number of Recuperators } \\
\hline & & & Operational & $\begin{array}{l}\text { Not in } \\
\text { Use }\end{array}$ & $\begin{array}{r}\text { Status } \\
\text { Unknown }\end{array}$ \\
\hline 1 & Box Forge/Reheat/Heat Treat. & 43 & 104 & 61 & 13 \\
\hline 2 & Slot Forges & 18 & 17 & 22 & 0 \\
\hline 3 & Aluminum Pot Melters & 16 & 14 & 2 & 0 \\
\hline 4 & Mold/Die Reheat Furnaces & 15 & 34 & 0 & 0 \\
\hline 5 & $\begin{array}{l}\text { Indirect Tube-type Reduction } \\
\text { Furnaces }\end{array}$ & 13 & 71 & 0 & 0 \\
\hline 6 & Rotary Calciners & 9 & 29 & 0 & 0 \\
\hline 7 & Retorts & 9 & 44 & 0 & 0 \\
\hline 8 & Carbottom Forge/Heat Treat. & 7 & 43 & 8 & 12 \\
\hline 9 & Aluminum Reverberatory & 5 & 0 & 7 & 1 \\
\hline 10 & Solder Pots & 5 & 5 & 0 & 0 \\
\hline 11 & Annealing & 4 & 5 & 1 & 1 \\
\hline 12 & Muffle & 4 & 14 & 2 & 0 \\
\hline 13 & Lead Melters/Heat Treat. & 4 & 10 & 2 & 0 \\
\hline 14 & Pusher & 2 & 14 & 4 & 0 \\
\hline 15 & Rotary Hearth & 2 & 8 & 0 & 8 \\
\hline 16 & Ladle Preheaters & 2 & 0 & 2 & 0 \\
\hline 17 & Clay/Pottery Kilns & 2 & 2 & 2 & 0 \\
\hline 18 & Misc. & 5 & 1 & 4 & 4 \\
\hline & TOTALS & 165 & 415 & 117 & 39 \\
\hline
\end{tabular}


for forging, reheating, or heat-treating metals was the most common type that GTE selected for heat recovery, accounting for $26 \%$ of the furnaces. One hundred seventy-eight recuperators were installed on these box furnaces, of which 104 or $58 \%$ are still operational. The slot forge furnaces were the next popular category with 18 furnaces outfitted with 39 recuperators of which only $43 \%$ are in operation. None of the aluminum reverberatory furnaces or ladle preheaters are currently recuperated. However, the success rate on pot melters, tube furnaces, rotary, retorts, and heat-treating furnaces was high.

If one considered the performance of the recuperators based on their operating temperature, shown in Table 4, one finds that $87 \%$ of those installed on furnaces at $2000^{\circ} \mathrm{F}$ and below are still operating, while only $57 \%$ of those installed at temperatures above $2000^{\circ} \mathrm{F}$ are still operating. The recuperator performance based on size is shown in Table 5. GTE manufactured the recuperators in three sizes, 0.6, 1.0, and 1.5 million Btu/h and these are $10 \times 10 \times 10$ in., $12 \times 12 \times 12$ in., and $12 \times 12 \times 18$ in., respectively. Eighty-nine percent of the small units are still operating, while $78 \%$ of the medium size units were operational and only $57 \%$ of the larger units were still operating.

\subsection{COMMON PROBLEM AREAS}

The early installations suffered from two problems that were unrelated to the recuperator but nevertheless part of the recuperation system. One problem was with the burners and the other was with the control system. However, after a year's experience with recuperation, both the burner companies and GTE were able to benefit from these experiences and the necessary modifications were successful. There were two problems that could be traced to the recuperator; these were attack from corrosive elements in the exhaust gases and plugging from particulate matter. These problems will be described here based on conversations with the industrial users and GTE engineers.

\subsubsection{BURNER PROBLEMS}

The burners for the combustion of the natural gas and oil with the preheated air were provided by Eclipse Inc., Hauck Manufacturing Co., North American Manufacturing Co., and Selas Corporation.

For preheat air temperatures of less than $600^{\circ} \mathrm{F}$, room-temperature burners were used and seemed to work satisfactorily. The initial hot-air burners designed for temperatures of $800^{\circ} \mathrm{F}$ and above were simple modifications of the room-temperature burners and some problems 
Table 4

Recuperator Performance By Operating Range

\begin{tabular}{lrrr} 
& $\geq 2000 \mathrm{~F}$ & $\leq 2000 \mathrm{~F}$ & $\frac{\text { Totals }}{2}$ \\
Operating & 159 & 256 & 415 \\
Not in Use & 93 & 24 & 117 \\
Unknown & 25 & 14 & 39 \\
\hline Totals & 277 & $\mathbf{2 9 4}$ & $\mathbf{5 7 1}$ \\
\hline
\end{tabular}

Table 5

Recuperator Performance by Size

\begin{tabular}{lcccc}
\hline Size MM Btu/h & $\mathbf{0 . 6}$ & $\mathbf{1 . 0}$ & $\mathbf{1 . 5}$ & Totals \\
\hline Operating & 182 & 92 & 141 & 415 \\
Not in Use & 6 & 19 & 92 & 117 \\
Unknown & 17 & 7 & 15 & 39 \\
\hline Totals & $\mathbf{2 0 5}$ & $\mathbf{1 1 8}$ & $\mathbf{2 4 8}$ & $\mathbf{5 7 1}$ \\
\hline
\end{tabular}


developed. One problem resulted from the cracking of the natural gas because of heating from the preheated air. This resulted in carbon and soot deposition. The alloy steel gas supply tube was surrounded by the preheated air which caused the cracking of the gas. This was later modified by design changes, and insulation was provided to keep the natural gas from attaining temperatures of above $600^{\circ} \mathrm{F}$.

Another problem with the early burners was flame instability and flash back, particularly at low-fire conditions. The early hot-air burner designs had failed to account for the increased flame velocity due to the higher temperature air and natural gas. At low-fire conditions, flash back would occur into the alloy steel gas supply tube and tube failure resulted. These problems were eventually corrected and burners available today are working satisfactorily with preheat temperatures in excess of $1200^{\circ} \mathrm{F}$.

\subsubsection{COMBUSTION CONTROL PROBLEMS}

The provision of adequate air:fuel ratio controls as well as furnace pressure control are very important parts of the recuperation system. In most applications, the excess air is maintained at about $10 \%$. Higher amounts of excess air, which may be required in certain applications to obtain higher convective heat transfer rates in the furnace, would result in more fuel being used. In applications such as forging, excess air may be kept at about $5 \%$ to prevent excessive scaling of the work piece which results in loss of material as well as shorter life of the forging dies. When a furnace is recuperated by preheating the combustion air, the penalty in fuel usage when using higher excess air rates is not as severe in terms of available heat ${ }^{5}$ as with an unrecuperated furnace. Nevertheless, furnace operators continue to maintain low excess air rates on most of their furnaces.

The most common method of controlling a furnace without recuperation is to balance the gas pressure with the air pressure with a pressure balancing regulator. Since the mass flow rate of the air is a function of pressure and temperature and the temperature of the unrecuperated air stream is reasonably constant, the air:fuel ratio is maintained reasonably constant. In a recuperated furnace, the combustion air temperature can vary from ambient at start-up to about $1200^{\circ} \mathrm{F}$ at high-fire operation. In this case, the control techniques commonly used are mass flow control where the fuel pressure is proportional to the mass flow of air or cross-connected control where the fuel pressure is proportional to the air pressure. With either technique, the fuel can be controlled by the air stream from upstream of the recuperator (cold side) or downstream of the recuperator (hot side). Electronic mass flow controls may also be used but these are difficult to justify economically because of their cost and resultant longer paybacks. 
When controls are set at low excess air rates, and some leakage around the seals occurs, the cold-side mass flow control cannot compensate for this and less air is supplied to the burner with the possibility that fuel-rich conditions may prevail in the burner and furnace. When this hat pens, combustion will take place at the point of leakage at the seals resulting in excessive temperatures being attained in the area of the leak and subsequent damage to the cordierite material. Often the area of the matrix near the leak may soften, melt, or be stressed enough that cracks form and the leakage increases. The ceramic matrix continues to deteriorate until leakage becomes excessive and the matrix must be replaced. If the hot-side mass flow control is used, the control system must operate effectively because as the remperature of the air increases, the air:fuel ratio decreases and the stoichiometry shifts to the richer side.

Operation of the furnace under fuel-rich conditions should be avoided. However, it is not uncommon to notice flames coming out of the exhaust side of the recuperator or eductor on top of the furnace. Sometimes when this happens, the furnace operators continue to operate the furnace under fuel-rich conditions in order to save the load in the furnace. The recuperators are considered expendable in these cases and are sometimes removed or replaced if the leakage becomes excessive. 'The pressure-compensated device 4 that GTE offers as standard equipment effectively maintains proper stoichiometric conditions in the furnace.

The pressure in a furnace chamber is usually maintained slightly above atmospheric so that a small volume of combustion products would leak out of the chamber. Belowatmospheric operation is avoided because that would draw cold outside air into the furnace, resulting in more fuel usage as well as poor temperature distribution in the furnace cavity. When a furnace is recuperated, the additional pressure drop in the recuperator exhaust passages could result in more combustion products escaping through cracks in the furnace. As deposits collect in the exhaust passages, the exhaust side pressure drop in the recuperator increases and less combustion products flow through the recuperator, resulting in lower air preheats and more fuel consumption. This can be easily avoided by using exhaust fans ar eductors on top of the recuperator exhaust to control the furnace cavity pressure and maintain the exhaust flow through the recuperator. On most of the systems sold by GTE, eductors and pressure controls are commonly used. The one furnace type where pressure control is very critical is the slot forge furnace where exhaust coming out of the slot is to be avoided to protect the operator. Recuperated slot forge furnaces present more difficulties in mass flow and pressure controls and the lower retrofit success rate bears this out. 


\subsubsection{RECUPERATOR PLUGGING}

The GTE recuperator is very compact, and the exhaust gas passage sizes are usually 0.200 $x 0.680$ in., but could be as low as $0.125 \times 0.680$ in. before the green matrix is fired. After firing, the product passage sizes are somewhat smaller because of shrinkage. Because of its compact nature, the GTE ceramic recuperator is ideally suited for processes that have clean exhaust gas streams. Processes where the exhaust stream is particulate laden should be avoided as the particulates would tend to plug the exhaust gas passages. This unit could not be used in processes fired by pulverized coal.

Certain types of particulate plugging can be corrected by periodic cleaning by means of a soot blower or an air-lance system. The latter has been used effectively by some industrial users. There are other types of particulates, which may be close to their softening point that are tacky and build up into a deposit that cannot be easily removed by an air iance. These type of deposits create a problem and cleaning by means of a chisel or by ramming a welding rod through, as a few users did, most often cracks the ceramic matrix. These types of applications are not compatible with the GTE recuperator. High-temperature processes in which a material is vaporized and carried through with the exhaust gases should also be avoided because that material would condense in the recuperator and plug it. An example of this type of plugging could be a glass tank exhaust stream. GTE's experience indicated that there were several processes, first thought to be clean, that resulted in plugging problems. A few of the experiences of plugging are discussed below. When existing furnaces need relining, it is now becoming the normal practice to reline the furnaces with fiber because of its better insulating properties. After continuous use some of the fiber is carried by the exhaust gases and is deposited in the recuperator. Two industrial users (Nos. 10 and 55) experienced some plugging problems, but these were easily resolved by cleaning the recuperators during normal shutdown.

Indirect natural gas-fired tube furnaces are clean operations that suit the compact GTE recuperator. However, the tubes oxidize and deteriorate with use and occasionally fail. When failure occurs the powders treated in the tubes end up in the furnace and subsequently in the recuperator. Most often these deposits can be easily removed and the recuperators reused. Typical examples are the GTE tube furnaces for tungsten and molybdenum reduction (No. 24) and the Pfizer (No. 52) furnaces for reduction of red iron oxide. In the latter case, the iron oxide seemed to have made the cordierite very brittle and cracks formed which resulted in more leakage of air into the exhaust gas stream. The increased leakage could lead to fuel-rich conditions in the furnace if not monitored and corrected.

This type of plugging also was experienced by Pfizer (No. 51) in the productions of 
calcium metal in retort furnaces. After extended use, the retorts could fail spilling the contents into the furnace. The calcium that then deposits in the recuperator corrodes the cordierite material. The recuperators lase for about 18 months in this application, but Pfizer is very satisfied with the paybacks and, as a result of the first DOE project, have eight furnaces equipped with the GTE recuperators.

Molybdic oxide plugging was experienced by several plants. Molybdenum oxidizes very rapidly at high temperatures. In fact, when a billet of molybdenum is heated in a furnace, yellow dust escapes through the exhaust or through the furnace door when it is opened. If a high moly-alloy steel is being heated for forging (Nos. 23, 62, 63) over a period of time, the recuperator would get plugged with the oxide. They would have to be cleaned periodically. Often, in the preheating of molds and dies, these molds are set down in metal trays which are then introduced into a pusher furnace. Howinet Turbine (Nos. 32,33) experienced moly-oxide plugging on their die reheat furnaces which was traced to the alloy steel trays that held the investment dies. This problem was easily solved by using trays made from alloy steels that contained less molybdenum.

The only kettle furnace application was a zinc kettle at Eastern Alloys in New York (No. 20). The zinc oxide that plugged the recuperator could not be removed easily. It was also not established whether the zinc would corrode the cordierite material.

Two ladle preheaters were recuperated, one for aluminum (No. 2) and one for steel (No. 35). In both cases, the recuperators plugged up with dross and other material from the ladle. Ladle preheaters, therefore, are not a good application for the GTE recuperator.

\subsubsection{CORROSIVE ATTACK}

One application that GTE has concentrated on is alloy steel forging furnaces. These are mostly box-type furnaces that operate at between $2250^{\circ} \mathrm{F}$ and $2350^{\circ} \mathrm{F}$ depending on the type of alloy being worked. Most of the furnaces were nat "ral gas fired and the exhaust gases were expected to be clean. However, at ten plants (Nos. 7, 16, 23, 29, 41, 42, 47, 60, 76 and 87) problems arose with the leaking recuperators causing the preheat air temperatures to drop. As the leaks got gradually worse, the furnaces would run fuel-rich and then the recuperators rapidly deteriorated. In the beginning, it was thought that the recuperators may have been faulty or that the furnace operators had run the furnace at fuel-rich conditions, causing the recuperators to crack. What was puzzling was that there were several plants where similar box forge furnaces were operating satisfactorily with tha same fuel and at the same temperatures. Initially, the problem recuperators were replaced, but replaced matrices soon suffered the same 
fate.

GTE analyzed several of the failed recuperators in the laboratory and found traces of sodium and potassium. The source of the sodium and potassium was traced to the ingots that were processed through the furnace. All of the furnaces at the ten plants processed raw ingots either continuously or on occasion. When molten steel is poured into an ingot, salts of sodium, potassium, calcium, etc., are placed on the top of the ingot. These are referred to as topping compounds. When these raw ingots are reheated in the recuperated furnace, the alkali deposits in the cordierite matrix and corrosive attack begins. The alkali metals form lower temperature eutectics with cordierite, resulting in softening and cracking of the matrix. Scott Forge (No. 60), a large progressive forge shop outside Chicago, installed five sets of the GTE recuperators on one of their forge furnaces, all of which failed. They sent a failed matrix to an independent laboratory and found that $21000^{\circ} \mathrm{F}$ eutectics were formed. With exhaust gases at $2350^{\circ} \mathrm{F}$, it is easy to understand why the recuperators failed. Scott Forge installed 6 sets of Hague International's SiC tubular recuperator on a furnace, all of which failed due to alkali attack. Because of their interest in conservation, they then installed Hot Works metal units and all four failed relatively quickly. They concluded that it was not economical to recuperate furnaces that processed raw ingots containing topping compounds.

Several of the forge shops tried cutting off the tops of these ingots but could not completely get rid of the alkali metals, and the cordierite matrix failed. One plant that is satisfied with their fuel savings but would like longer recuperator life is Hawker Siddeley (No. 29) in Nova Scotia, Canada. This plant is supplied with hot ingots shipped in insulated containers, therefore they are unable to cut off the tops. Their furnaces are oil-fired and their paybacks (with 50\% savings) are less than a ycar. Their engineer would continue to replace the failed cubes as long as it was economical to do so. In the case of Cape Ann Forge (No. 76), the plant is located by the seashore and salt in the air may have further contributed to the cube failure.

McWilliams Forge (No. 42) operates a box forge to reheat copper for forging into aircraft parts. The furnace has three recuperators. While the copper is being reheated, charcoal is thrown into the the back of the furnace probably to prevent the formation of copper oxide. However, the two recuperators closest to the back of the furnace failed and their replacements failed as well. It was found that the charcoal contained potassium which was the cause of the failure.

None of the recuperators on the Aluminum Remelt furnace (No.13) or Aluminum Reverberatory furnaces (Nos. 36, 43, 77 and 84) are in operation because of attack by sodium. Callen Mfg. Corp. in North Lake, Illinois uses a white powder called "Smokeless Flux" for 
fluxing in their remelt furnace. Some of the powder deposited in the recuperator and could not be removed by an air lance. The flux may also have contained some sodium which could have attacked the cordierite, since the exhaust gases entered the recuperator at $2200^{\circ} \mathrm{F}$. The aluminum reverberatory furnace recuperators were failures as well because of the fluxing agents used. It soon became evident that aluminum remelt/reverberatory exhaust gases are dirty gases and these applications are not suitable for the GTE recuperator.

The metal lead may also be considered a poor application with respect to attack on cordierite. Two lead melters (Nos. 85 and 86) operating at $1800^{\circ} \mathrm{F}$ were recuperated. In both cases, the recuperators plugged and were destroyed. The other two lead operations were annealing furnaces where steel spring wire (No. 5) and steel bailing straps (No 66) are tempered. In both these plants the operations are similar although furnace temperatures are $2300^{\circ} \mathrm{F}$ and about $2000^{\circ} \mathrm{F}$ to $2100^{\circ} \mathrm{F}$, respectively. Both furnaces are still operating, but the recuperators have done better on the furnace operating at the lower temperature. Large stainless steel pots, $4 \mathrm{ft}$ wide and $12 \mathrm{ft}$ long, contain the molten lead at $1600^{\circ} \mathrm{F}$ for tempering steel and are supported at the bottom by piers made of firebrick. The natural gas burners fire low and the exhaust gases blow by the steel pot. Multiple straps,at least 14, and wires continuously pass through the lead. Molten lead falling on the firebrick forms a eutectic that destroys the brick rapidly. The brickwork on these furnaces is rebuilt every 6 to 12 months at American Spring Wire but lasts longer at Stanley Works.

There are three distinct problems with the recuperators. First, if the lead on occasion falls into the combustion chamber, it vaporizes and deposits in the recuperator, causing some plugging. The second problem relates to the firebrick which contains some potassium and sodium that is released in firing the brick and deposits in the ceramic matrix. Regular replacement of the fire- brick would hasten the demise of the ceramic matrix. Finally, it is possible that the lead and cordierite form lower meling eutectics that may soften or crack the matrix. If lead can cause the firebrick to deteriorate that fast, it surely must have an affect on the cordierite. It is possible that the eutectics formed with lead could soften at temperatures as low as 2200 or $2300^{\circ} \mathrm{F}$. The fact that American Spring Wire operates at $2300^{\circ} \mathrm{F}$ while Stanley Works operates between 2000 and $2100^{\circ} \mathrm{F}$ may explain why the former's recuperators have to be replaced more often. It would appear that American Spring Wire should operate the furnace at a lower temperature unless this would adversely affect their production. It would appear that applications involving molten lead are not the best for the GTE recuperator. 


\section{COMPARATIVE ANALYSIS OF THE GTE RECUPERATOR APPLICATIONS}

The 89 plants presented in Tables 1 and 2 have been categorized into their respective Standard Industrial Classification (SIC) codes and presented in Table 6 together with information on specific process energy (oil and gas only) consumption and furnace population. These two items will be discussed further in this section.

\subsection{Oil/Gas Consumption for Industrial Process Heat}

In assessing the impact that the GTE recuperator has made in terms of energy savings potential, one must consider the energy used for process heat by the various types of industries in which the recuperator was installed. The energy use data in Table 6 were obtained by PAR Enterprises from several sources ${ }^{6.11}$. In using energy data from the various sources, one must be cautious and recognize that differences exist in the absolute values, but the numbers can be useful for impact analysis and indicating trends and directions to be pursued. The energy values in Table 6 were not authenticated; and differences between the values were not reconciled among the various sources, as this was considered outside the scope of this work. The Census of Manufacturers ${ }^{7}$ data is widely used and the EPA NEDS data base ${ }^{9}$ has useful information on energy, unit processes and equipment, collected from 34,000 plants in the United States.

In evaluating the furnace energy consumption for an aluminum remelt furnace, for example, one may start with the Census figures for fuels and electric energy consumed and subtract the electric energy, fuels used for feedstock purposes, for generating steam, for space heating and for non-process heating use. PAR Enterprises, Inc., performed such a task for GTE Products Corporation in 1982 and determined the oil and gas consumption for the major 4-digit industries. The entire listing from that study is presented in Appendix A. Those industries in which the recuperator was installed are listed in Table 7.

As can be seen from Tables 6 and 7, GTE has targeted the metals industries except for two installations in the Structural Clay and Pottery Products area. In terms of energy consumption, that decision was probaìy correct because the metals processing industries are quite energy intensive. Another reason for selecting these industries was probably the relative cleanliness of the exhaust streams which are primarily fueled by natural gas and oil. However, what was initially thought to be clean streams in the pottery kilns, aluminum remelt furnaces, and steel forging furnaces, in reality were corrosive streams that contained sodium and potassium which corroded both metals as well as ceramics. Nevertheless, most of the 


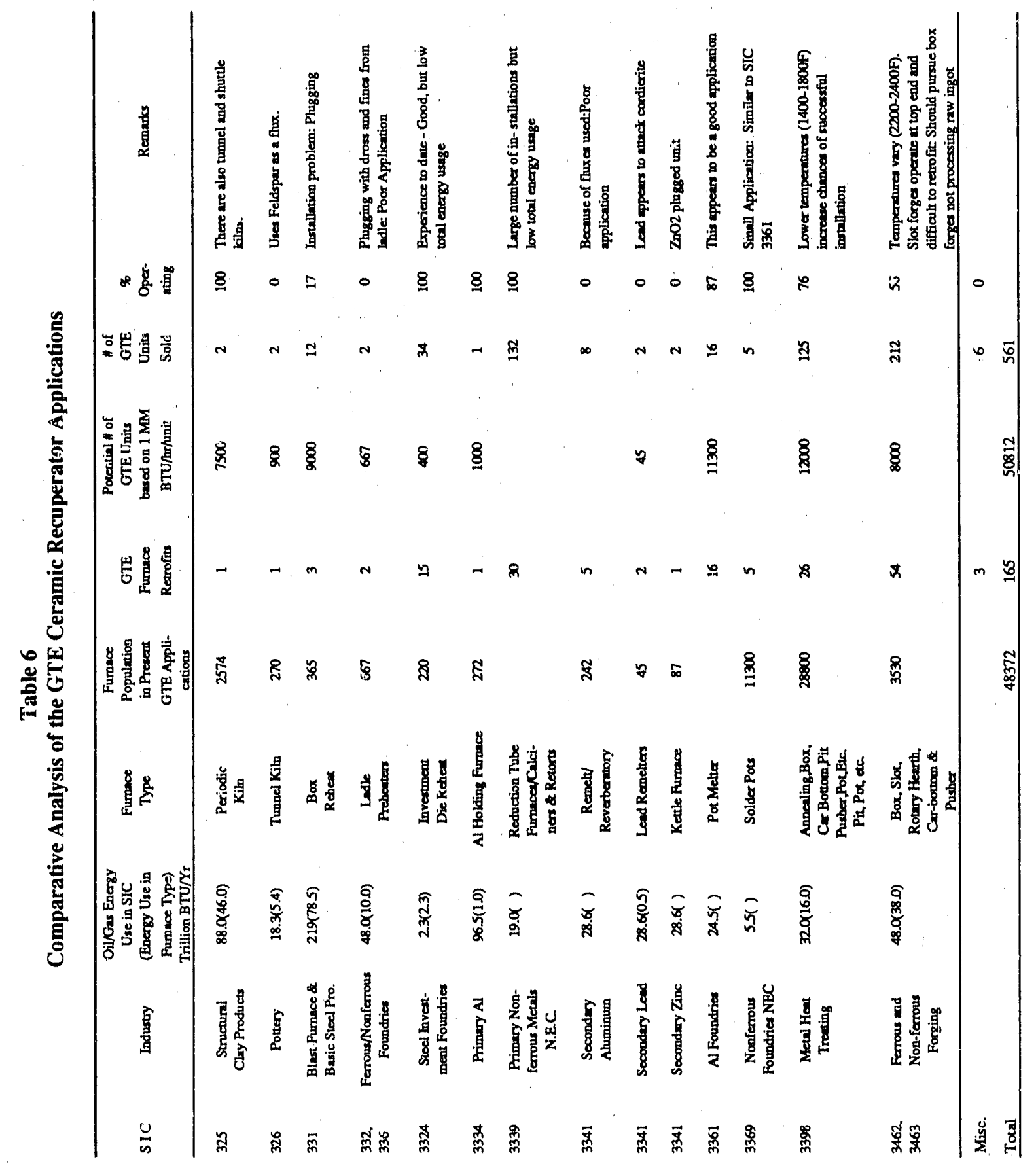


Table 7

Oil \& Gas Consumption for Direct Process

Heat for GTE Targeted Industries

\begin{tabular}{|c|c|c|c|}
\hline $\begin{array}{c}\text { National } \\
\text { Rank }\end{array}$ & $\begin{array}{c}\text { Standard } \\
\text { Industrial } \\
\text { Code }\end{array}$ & Industry & $\begin{array}{c}\text { Energy } \\
\text { Consumption } \\
\text { (Trillion Btu/yr) }\end{array}$ \\
\hline 3 & 3312 & Blast Furnaces and Steel Mills & 688.2 \\
\hline 11 & 3251 & Brick and Structural Clay Tile & 50.4 \\
\hline 14 & 3321 & Gray Iron Foundrics & 41.2 \\
\hline 17 & 3462 & Iron and Steel Forgings & 36.6 \\
\hline 23 & 3341 & Secondary Nonferrous Metals & 27.4 \\
\hline 30 & 3361 & Aluminum Foundries & 20.7 \\
\hline 31 & 3325 & Steel Foundries, NEC & 19.3 \\
\hline 37 & 3255 & Clay Refractories & 16.8 \\
\hline 42 & 3317 & Steel Pipes and Tubes & 13.6 \\
\hline 48 & 3398 & Metal Heat Treating & 11.9 \\
\hline 49 & 3259 & Structural Clay Products, NEC & 11.5 \\
\hline 55 & 3322 & Malleable Iron Foundries & 8.4 \\
\hline 61 & 3261 & Vitreous Plumbing Fixtures & 6.4 \\
\hline 67 & 3313 & Electrometallurgical Products & 4.7 \\
\hline 70 & 3264 & Porcelain Electrical Suppliers & 4.0 \\
\hline 73 & 3369 & Nonferrous Foundries, NEC & 3.9 \\
\hline 77 & 3463 & Nonferrous Forgings & 3.1 \\
\hline 80 & 3269 & Pottery Products, NEC & 2.8 \\
\hline 85 & 3262 & Vitreous China Food Utensils & 2.0 \\
\hline 87 & 3362 & Brass Bronze, Copper Foundries & 1.9 \\
\hline 89 & 3324 & Steel Investment Foundries & 1.5 \\
\hline 91 & 3263 & Fine Earthernware Food Utensils & 1.4 \\
\hline 97 & 3315 & Steel Wire and Related Products & 1.0 \\
\hline 102 & 3334 & Primary Aluminum & 0.8 \\
\hline
\end{tabular}


applications were suitable to the particular ceramic material, as evidenced by the $72 \%$ success rate in all the United States and Canadian installations.

Besides the metal industries, there are several other industries where the GTE recuperator could be applied. These industries are large energy consumers and use furnaces/reactors/ heaters that are fueled by natural gas or oil and produce relatively clean exhausts at high enough temperatures to justify economical recuperation. Chemicals and Allied Products (SIC28) are large energy consumers that have reactors, reformers, and fired heaters with exhausts suitable for the GTE recuperator. The same may be said about Petroleum Refining (SIC 29). In the Stone, Clay and Glass Industries (SIC 32), one would have to be more selective in the applications because of dirty exhaust gas streams. For example, structural clay products (SIC 326) may have cleaner exhaust streams than pottery products (SIC 326) which would use potentially damaging fluxing agents. Exhausts from glass tanks and cement kilns would not be suitable for the GTE recuperator because of corrosive compounds and particulates.

Thus, the chemicals and petroleum refining industries appear to have possibilities for using the GTE recuperator. The reason why GTE did not pursue these opportunities has been because we lacked the infrastructure needed to successfully market and support the product in this segment. In marketing the "Super Recuper", GTE relied solely on the burner manufacturers to sell their product to the industrial consumer. This worked very well in the metals indıstries where the burner companies were supplying combustion equipment to small foundries and forge shops .

However, the burner companies do not have the same relationship with the large plant operations, such as refineries and chemical plants. Most of these plants are technically sophisticated and have their own combustion department, and most of them fabricate their own furnaces and reactors. This may have been one reason why the petroleum and chemical industries were not targeted for recuperation.

The other group that GTE relied on to market the recuperator was the furnace manufacturers who could have promoted use of the technology. However, because of the poor business climate in the metals area, few, if any new furnaces were sold and furnace manufacturers were lucky to have survived financially.

\subsection{FURNACE POPULATION}

In 1981, PAR Enterprises, Inc. had conducted a survey of industrial furnace equipment ${ }^{12}$ that provided some estimates of furnace types and population compiled from the published literature. Table 8 shows the number of furnaces that generate clean exhaust gases and 
Table 8

Furnace Energy Consumption/Population ${ }^{12}$

\author{
Energy Co:sumption \\ Trillion-Btu/yr
}

Furnace

Population
Clean Exhausts

Dirty Exhausts

Electric Furnaces
1,144

1,687

303
145,800

14,500

31,500
Totals
3,134
191,800

contaminated exhaust gases. The contaminated gases and energy consumption were primarily based on the EPA NEDS data base ${ }^{9}$ and are defined as gases containing large amounts of particulates or corrosive elements. The NEDS data base was based on information supplied by 34,000 plants in the United States, and information on contaminants in exhaust streams may not have been supplied for obvious reasons.

Further, natural gas-fired systems were usually taken as clean exhausts; whereas, one now considers soaking pits, aluminum remelt furnaces, and even box forge furnaces to have dirty exhausts because of corrosive elements such as sodium and potassium salts. Therefore, the information provided in Table 8 should not be used without further investigation. It is interesting to note that furnaces that produce clean exhausts greatly outnumber those with dirty exhausts but that energy used in the latter is more than that used in the clean operation. The furnace study ${ }^{12}$ also indicated that only $30 \%$ of the furnaces producing clean exhausts were recuperated, while $70 \%$ of those producing contaminated exhausts were being recuperated. These numbers indicate that there are large potential markets for the GTE ceramic recuperator.

Referring to the furnace population figures in Table 6 , it would appear to be more fruitful to pursue SIC 325 rather than 326 not only because of a larger number of furnaces available and larger potential for energy savings, but also because of cleaner exhausts in the case of the structural clay products as compared with pottery products. 
In the blast furnace and steel products industry (SIC 331), oil and gas use amounted to about 897 trillion Btu/year. Most of this, or about 688 trillion, was used in SIC 3312. Here, the iron ore reduction and steel refining operations do not have opportunities for this type of recuperator. At one time there may have been at least 1800 soaking pits using about 120 trillion Btu, but this is not an application for the GTE recuperator because these are large furnaces that process raw ingots with topping compounds. However, reheating slabs, blooms, billets, and bars, if selectively chosen, could offer opportunities for the ceramic recuperator. There are 365 box-type reheat furnaces but there are also 589 pusher-type furnaces in this operation that GTE had not attempted to retrofit.

The SIC 331 includes a number of operations that appear to have excellent possibilities for the GTE recuperator. These are annealing and heat-treating operations involving 4535 furnaces (not included in SIC 3389) in the steel mill that consumes about 111 trillion Btu/year. These are listed in Table 9 and appear to be clean, low-temperature processes quite suitable for the GTE recuperator.

The iron and steel foundries (SIC 332) and nonferrous foundries (SIC 336) have been well sought out by GTE. Mold and die reheating furnaces have been successful retrofits as have been aluminum pot melters. These are relatively clean operations. However, ladle preheaters are to be avoided because of plugging problems. There were, however, several types of furnaces that GTE did not retrofit. There were 115 open hearth furnaces, 1737 reverberatory, and 190 rotary furnaces, all operating from 1200 to $2900^{\circ} \mathrm{F} ; 3700$ diecast holding furnaces operating at $1200^{\circ} \mathrm{F}+$; and 220 investment cast holding furnaces operating at over $2000^{\circ} \mathrm{F}$. In addition, there are about 1400 radiant and direct heat treat furnaces that operate at up to $1700^{\circ} \mathrm{F}$ that are not included in SIC 3398. The primary and secondary nonferrous metals do not appear to be good applications for the GTE recuperator either because of the small energy consumption or dirty exhausts. Aluminum remelt furnaces, lead melters, and zinc kettles have dirty exhaust streams that attack the cordierite recuperator material.

SIC 3339, primary nonferrous metals had a number of applications, most of which were in GTE's Towanda facility. These were indirect type, lower operating temperature furnaces for reducing tungsten and molybdenum compounds. The SIC energy consumption is low and there are not many plants in the United States that have these types of operations. One cannot deny, however, that GTE has saved energy and some of those furnaces are still operating with the original recuperators.

The nonferrous metals rolling and drawing operations (SIC 335) use about 126 trillion Btu/year of purchased fuels. This area was not addressed by GTE. There are smelting, holding, heating and annealing/heat treating operations in this SIC with an estimated 4,475 furnaces. 
The metal heat treating industry, SIC 3398, appears to be a potentially profitable area for GTE to market much more extensively. There are a number of annealing/normalizing, hardening, tempering, carburizing, and other operations that are relatively low-tempeature operations with clean exhausts ideally suited for the GTE recuperator. However, there are many small furnaces and batch-type operations. For instance, there are an estimated 38,400 batch-type annealing/normalizing furnaces alone. These batch type of furnaces have not been considered in the furnace population count of Table 6 because the hours of operation are not known and therefore it could not be determined whether the economics would be attractive.

GTE appears to have concentrated the most in the steel forging industries. There were about 960 forge shops in 1980 but the recent business climate has been poor and a number of companies have closed their operations. While the alloy steel forge furnaces consume a large quantity of energy, they operate at very high temperatures between 2250 and $2400^{\circ} \mathrm{F}$. At these temperatures, elements like sodium, potassium and calcium that originate either from the load (topping compounds) or from newly installed refractory could corrode the ceramic recuperator. Of the 212 units installed in these furnaces, only $56 \%$ are currently operating. Therefore, GTE needs to be more selective in these retrofits.

\section{CASE STUdies}

\subsection{OVERVIEW}

GTE has developed procedures to evaluate a recuperator returned for refurbishing. These procedures were established to gather feedback to the recuperator designer, the manufacturing department and the system designers that specify the ceramic recuperator. Recuperators returned to GTE have generally been operated until complete system failure occurred. Complete system failure is defined as the inability to obtain required process temperatures and/or required product throughput. The recuperator, once destroyed, leaks a quantity of combustion air that is so large that the preheated-air temperature, volume and pressure arebelow the levels required for proper operation. A degraded ceramic recuperator is generally exposed to excess fuel conditions in its last stages of operation. The excess fuel in the exhaust stream mixes with the leaking combustion air and combustion takes place inside of the recuperator. The potential to generate extremely high temperatures within the recuperator from this combustion was thought to be the cause for the melting of the face of the ceramic matrix often found on matrix elements returned for rebuild. Another possibility was the formation of a low temperature eutectic from reaction of the cordierite ceramic reacting 
with alkali metals often present in the glassy face of the ceramic. To fully understand the mode of failure of the ceramic matrix, ceramic recuperators were removed from service prior to failure during this contract effort. This allowed the investigation to proceed before some of the evidence was destroyed during the final stages of failure (excess fuel). This unique opportunity gave insight into the long term degradation of the ceramic.

\subsubsection{QUALITY ASSURANCE MEASURES}

The following procedures are followed prior to assembly of a ceramic matrix:

- The matrix is inspected for geometric tolerances

- The matrix must not contain visible cracks

- The matrix is tested for leakage and structural integrity, it

- must leak $<5 \%$ of the nominal air flow rating at $1 \mathrm{psi}$

- must survive a 5 psi pressure to the exhaust-side

- must survive a 5 psi pressure to the preheat-side

- Leakage must not be concentrated in one area (which would indicate an internal crack)

- The unit is assembled and housed and must leak $<5 \%$ of its nominal air flow rating at $1 \mathrm{psi}$

The housed recuperator test procedure requires that the preheat-air outlet be sealed off. The combustion air inlet is then attached to a 2 psi blower. A valve vented to the room is used to adjust the pressure actually delivered to the assembled matrix. The pressure in the first pass of the recuperator is monitored, and the flow into the recuperator is determined, by calculating the pressure drop across an orifice plate upstream of the recuperator. Percentage values are determined by the ratio of actual leakage to nominal air flow for each pressure. The recuperator ratings are listed in Table 9. Generally, a recuperator system must operate at a pressure of 0.5 psi under high-fire conditions. This pressure is determined by the burner's specifications.

The ceramic matrix is sealed inio the refractory lined metallic housing with a high temperature gasket (Figure 2). The gasket overlaps a 0.75 in.wide seal face on each of the corners of the ceramic cube. The seal face is formed by impregnating the ceramic with commercially available moldable aluminosilicate fiber. The moldable material is a slurry of $2600^{\circ} \mathrm{F}$ fiber suspended in a "water-glass" suspension (sodium-silicate). The sealed area reduces the effective heat transfer area of the recuperator. The area that is used to foster the multiple pass design is 0.5 in,high, and runs the entire width of the combustion air-inlet and combustion air-outlet faces of the recuperator. For example, the R0600 model is $10 \times 10 \times 10$ 
Table 9

GTE Recuperator Nominal Air Flow Ratings

\begin{tabular}{lrrr}
\hline MODEL \# & \multicolumn{1}{c}{ SIZE } & Btu Rating & Nominal Air Flow Rating \\
\hline R0600 & $10 \times 10 \times 10$-in. & $600,000-\mathrm{Btu} / \mathrm{h}$ & $6,600-\mathrm{scfh}$ \\
R1000 & $12 \times 12 \times 12$-in. & $1,000,000-\mathrm{Btu} / \mathrm{h}$ & $11,000-\mathrm{scfh}$ \\
R1500 & $12 \times 12 \times 18$-in. & $1,500,000-\mathrm{Btu} / \mathrm{h}$ & 16,500 -scfh
\end{tabular}

in, but the effective volume is $8.5 \times 8.5 \times 7.5 \mathrm{in}$.

The gasketed area then creates a .075 in.thick area without cross flow at the exhaust inlet section of the recuperator (dead area). This area generally operates at a temperature 200 to $500^{\circ} \mathrm{F}$ cooler than the exhaust gas temperature. The temperature of the ceramic in the area of cross flow is approximately equal to the average of the exhaust gases, and the combustion-air preheat-temperature. This unused area plays a critical role in the life cycle of the recuperator. The exhaust gases often contain contaminants that condense on the cooler ceramic. This ceramic reacts with the alkali materials and forms glassy materials that in time may seal off the exhaust inlet of the recuperator, rendering it useless. The concentration of contaminant is reduced in the "dead zone" by the cooled ceramic, and the area of crossflow is protected by the exhaust inlet dead area. This is illustrated in Figure 4.

\subsubsection{POST MORTEM ANALYSIS TECHNIQUES}

A "post mortem" analysis generally is as follows:

- Collect any residue or deposits loosely bound to the exhaust inlet and outlet

- Photograph and/or describe the housed matrix

- Leak test the housed matrix in a dead head test to determine the leakage flow at 0.25 , 0.5 , and $1 \mathrm{psi}$

- Remove the combustion air-inlet assembly and inspect for cracks and delamination of the ceramic

- Photograph and/or record findings

- Collect any debris, and analyze (qualitative emission spectrography) if not identifiable 
- Remove the matrix and pressure test it if intact (generally the unit is delaminated and/or melted, and must be removed in sections)

- Photograph the matrix as it is sectioned, and identify "white cells", cracking patterns, and corrosion patterns (if any)

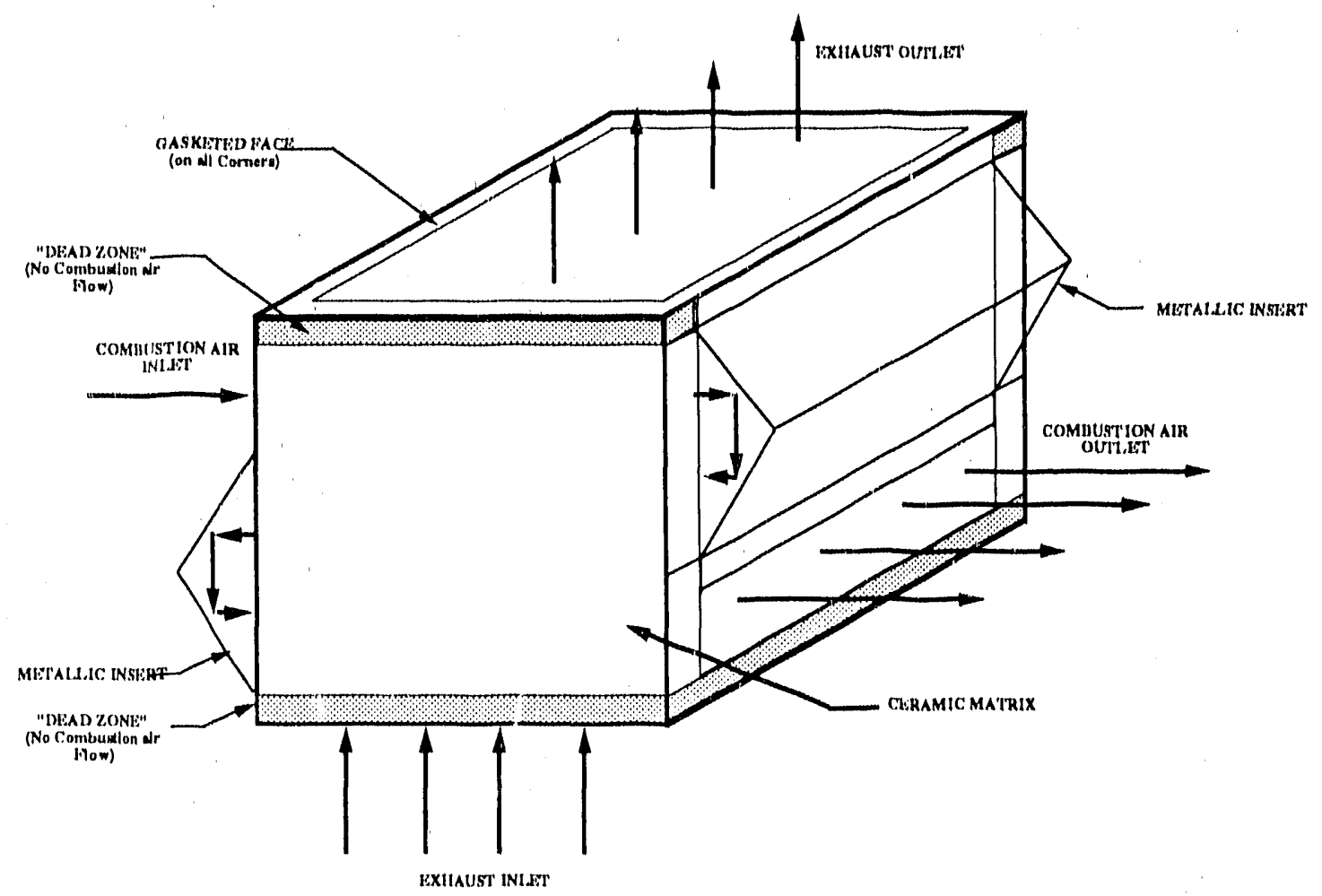

Figure 4

\section{GTE Ceramic Recuperator Flow Arrangement}

"White cells" are exhaust-gas passages that are still the color of an unused ceramic matrix. After use, regardless of the degree of cleanliness, temperature, or fuel type used on the application, the ceramic becomes darkened. A "white cell" is evidence of a crack that was present prior to recuperator operation. The cell fails to discolor because no exhaust gases ever pass through a cell with a crack. The pressure of the air in the combustion air channels (1 to 20 osi, depending upon input rate and system design) is significantly higher than the pressure in the exhaust gas channels (0.05-(0.15 osi). The higher pressure combustion air travels into the cracked exhaust channel, and then is directed towards the exhaust inlet and outlet section of the recuperator, where it mixes with the exhaust gases. These cells, when found, are 
generally few in number (<5). A large number of cells (cracks) would be screened by the leakage and pressure tests. Cracks found in the area of a "white cell" of an operating recuperator are generally long, straight hairline cracks. They are barely visible at umbient temperature. Hairline cracks form during the cooling portion of the firing cycle. Experience has shown that cracks that form early in the sintering process always result in irregular shape cracking patterns distinguished by a large gap (.010-in.) in the center section. A crack this large would be cause for fallure of the leakage tests. Most ceramic matrix elements have a leakage value of $1-2 \%$, and much (or all) of this value is associated with the leakage about the gasketed seals of the leak test apparatus or along the outside edges or the recuperator.

With this knowledge in mind, a postmortem that finds cracks other than those associated with "white cells" must assume significant thermal stresses were placed on the ceramic matrix, outside of those it was designed to tolerate, or that the ceramic is no longer capable of withstanding thermal stresses. A condition that results in cracking from thermal stress can cause failure of the multiple pass system. This would cause ambient air to impinge on cells heated to temperatures close to the exhaust gas inlet temperature. These failures are rare, and a simple inspection of the metallic inserts (warping) will confirm if the multiple pass design was compromised. The more common reason for crack formation is the chemical degradation of the ceramic. Conversion of the cordierite ceramic to glass, and/or a mixture of other ceramics such as mullite or spinel has been observed when gross cracking of the ceramic matrix is observed.

This analysis was preformed for virtually every ceramic recuperator refurbished at GTE since the outset of this contract effort. The historical data obtained from this effort, and the information obtained by removing recuperators prior to failure confirms that fallures are generally proceeding at a slow rate if trace contaminants are present in an exhaust stream. The rate is proportional to concentration and temperature. The fact that the units generally experience an excess fuel excursion prior to complete failure is due to degradation of the matrix. The degradation of the matrix may become more extreme during the excess fuel excursion, but the failure is generally not a result of the excess-fuel condition simply caused by control system failure. This finding was directly responsible for GTE's decision to specify that system designs must anticipate potential corrosion problems on applications typically thought to be clean. Even standard refractory brick has been shown to volatilize alkali contaminants

TaLle 10 details the elements sought in a typical qualitative analysis. Additionally, the table lists the detection ranges reported for each element sought. 
Table 10

Elements Sought and Detection Limits

During Spectrographic Qualitative Analysis

\begin{tabular}{|c|c|c|c|c|}
\hline $\begin{array}{l}\text { CHEMICAI, } \\
\text { SYMBOL }\end{array}$ & $\begin{array}{c}\text { CHEMICAL } \\
\text { NAME }\end{array}$ & & $\begin{array}{l}\text { REPORT } \\
\text { SYMBOL }\end{array}$ & $\begin{array}{r}\text { REPORT } \\
\text { RANGE }\end{array}$ \\
\hline $\mathrm{Ag}$ & Silver & 1 & $V_{i}$ & $10-100 \%$ \\
\hline $\mathrm{Al}$ & Aluminum & 1 & St & $5-50 \%$ \\
\hline As & Arsenic & 1 & $\mathbf{S}$ & $1-10 \%$ \\
\hline $\mathrm{B}$ & Boron & 1 & ST+ & $0.5-5 \%$ \\
\hline $\mathrm{Ba}$ & Barlum & 1 & ST & $0.1-1.0 \%$ \\
\hline $\mathrm{Be}$ & Beryllium & 1 & $T+$ & $0.05-0.5 \%$ \\
\hline $\mathrm{Bi}$ & Bismuth & 1 & $\mathrm{~T}$ & $0.01-0.1 \%$ \\
\hline $\mathrm{Ca}$ & Calcium & 1 & FT+ & $50-500 \mathrm{ppm}$ \\
\hline $\mathrm{Cd}$ & Cadmium & 1 & FT & $10-100 \mathrm{ppm}$ \\
\hline Co & Cobalt & 1 & VF+ & 5-50ppm \\
\hline $\mathrm{Cr}$ & Chrome & 1 & VF & 1-10ppm \\
\hline $\mathrm{Cu}$ & Copper & 1 & VVF+ & $0.5-5 \mathrm{ppm}$ \\
\hline $\mathrm{Fe}$ & Iron & 1 & VVF & $<1 \mathrm{ppm}$ \\
\hline $\mathrm{Ge}$ & Germanium & 1 & - & not detected \\
\hline $\mathrm{K}$ & Potassium & 1 & & \\
\hline $\mathrm{Li}$ & Lithium & 1 & & \\
\hline $\mathrm{Mg}$ & Magnesium & 1 & & \\
\hline $\mathrm{Mn}$ & Manganese & 1 & & \\
\hline Mo & Molybdenum & 1 & & \\
\hline $\mathrm{Na}$ & Sodium & 1 & & \\
\hline $\mathrm{Ni}$ & Nickel & 1 & & \\
\hline $\mathrm{P}$ & Phosphorus & 1 & & \\
\hline $\mathrm{Pb}$ & Lead & 1 & & \\
\hline $\mathrm{Sb}$ & Antimony & 1 & & \\
\hline $\mathrm{Si}$ & Silver & 1 & & \\
\hline $\mathrm{Sn}$ & Tin & 1 & & \\
\hline $\mathrm{Ta}$ & Tantalum & 1 & & \\
\hline Th & Thorium & 1 & & \\
\hline $\mathrm{Ti}$ & Titanium & 1 & & \\
\hline V & Vanadium & 1 & & \\
\hline W & Tungsten & 1 & & \\
\hline $\mathrm{Zn}$ & Zinc & 1 & & \\
\hline $\mathrm{Zr}$ & Zirconium & 1 & & \\
\hline
\end{tabular}




\subsection{TUNNEL KILN (Saxonburg Technical Ceramics - Saxonburg, Pennsylvania.)}

Figure 5 shows the two R 1500) ceramic recuperators on the Bickley roller hearth tunnel kiln at Suxonburg ceramics. The furnace is $40 \mathrm{ft}$ long. The operator is loading alumina setters that are used to transport alumina substrate through the furnace. Cycle times range between 1.7 and 2.7 hours. Recuperators are located on the preheated air zone of the furnace. The exhaust inlet temperature ranges between 2000 and $23000^{\circ} \mathrm{F}$. Combustion air is prehented to the 1200 to $1400^{\circ} \mathrm{F}$ range and is then ducted to burners in the hot zone. The hot zone operater at temperatures between 2800 and $29(0)^{\circ} \mathrm{F}$ at $10 \%$ excess air. Natural gas is the only fuel used. Exhaust gas mass flow rates are approximately $30 \%$ greater than the combustion air mass flow rate. This results in the unusually high preheated-air temperature, and means that the ceramic matrix operates hotter than usual.

Figure 6 shows the exhaust inlet of a recuperator pfter 15 months of service. Figure 7 shows the exhaust outlet of the same recuperator. The glassy-melted appearance on the inlet side and the powder coating on the exhaust outlet were sampled for spectrographic analysis. Leakage rates, and exhaust side pressure drop reduced the performance of the recuperator to the point that furnace temperature could not be maintained. Leakage rates were approximately $35 \%$ at 16-osi. Eight samples were submitted for spectrographic analysis. The results are listed in Table 11.

Approximately $85 \%$ of the free flow area of the exhaust inlet was covered with a brown, glassy-like material. The inside of the matrix was covered with a brown, fibrous and/or powdered material. The matrix was cracked, and a partial delamination occurred on one of the recuperators ( 2 units were investigated). The major contamints are identified in Table 11. The most important information is the composition of the glassy material (icicle) on the exhaust inlet section. The amount of alkali contrasts dramatically with the amount found in the ceramic matrix before operation (.01-.1\%), an increase of 10 to 50 times. Although phosphorus is present in the exhaust outlet, it does not appear to react with the ceramic, and it deposits in the cooler exhaust outlet sections of the recuperator (dew point must be in the range of 90()$^{\circ} \mathrm{F}$ ).

Sampling of the refractory brick and the mortar was undertaken in an effort to determine the potential of these materials as a source. Table 11 clearly indicates they are not potent candidates. The following is a list of possible sources of contaminant:

- The furnace refractory (one time exposure from initial burnout).

- The refractory mortar used (one time exposure from initial burnout).

- The $\mathrm{NaOH}$ wash utilized when changing the ceramic pins used to secure the ceramic rollers.

- A sintering aid in the $\mathrm{SiC}$ rollers (one time exposure from initial burnout). 


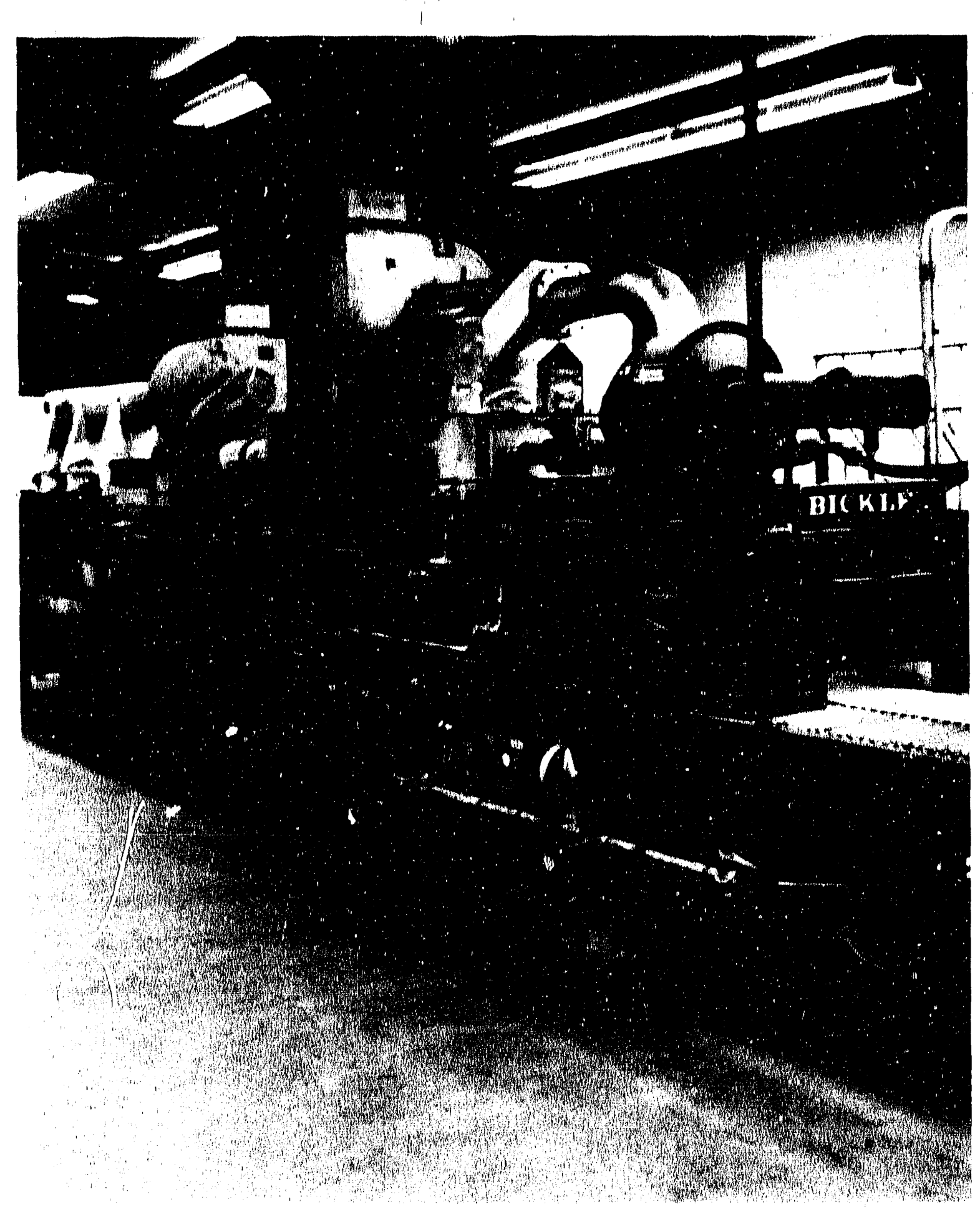

Figure 5

R1500 Recuperators on the Bickley Roller

Ilearth Tunnel Kiln at Saxonburg Ceramics 


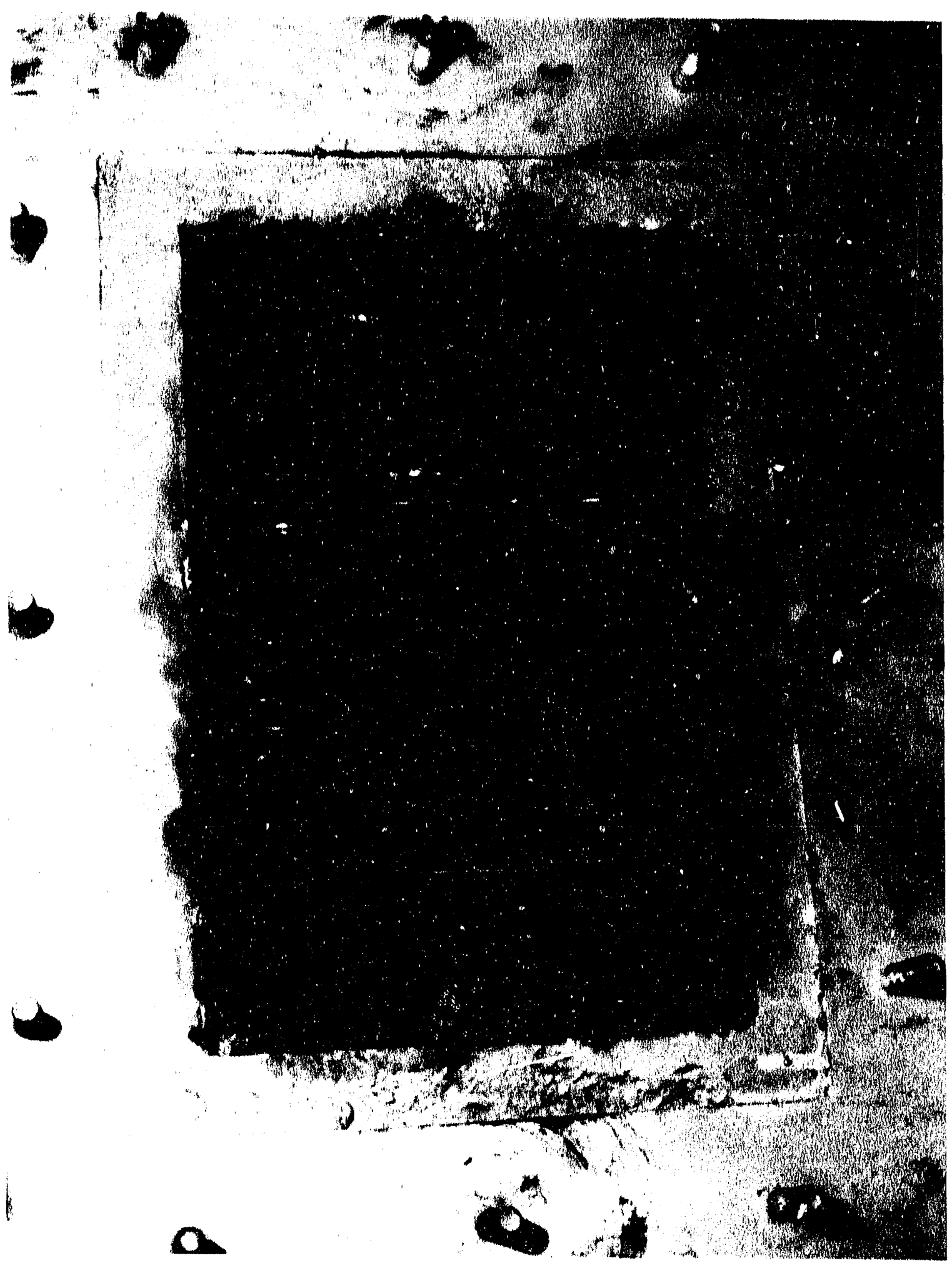

Figure 6

R1500 Recuperator Exhaust Inlet After

15 Months of Operation at Saxonburg Ceramics 


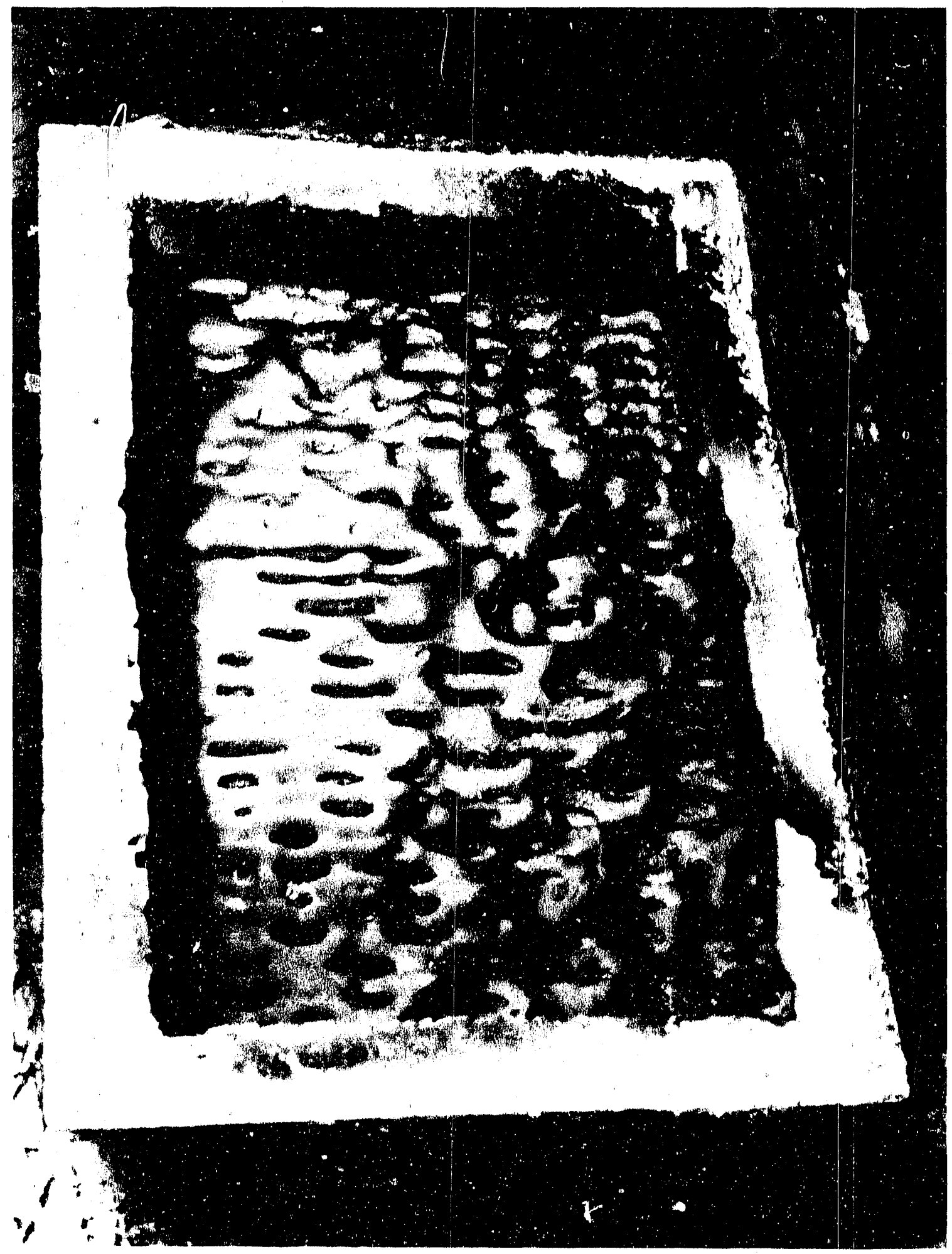

Figure 7

R1500 Recuperator Exhaust Outlet After

15 Months of Operation at Saxonburg Ceramics 
Table 11

Spectrographic Qualitative Analysis

of Samples from Saxonburg Ceramics

\section{Sample Description}

$\begin{array}{lllllllll}\text { Al } & \mathrm{Cr} & \mathrm{K} & \mathrm{Li} & \mathrm{Na} & \mathrm{P} & \mathrm{Pb} & \mathrm{Si} & \mathrm{Ti}\end{array}$

Grey-brown material hanging down

from the Recuperator exhaust inlet

$\begin{array}{lllllllll}V S & T & S & S T & S & T & & & \end{array}$

Residue from exhaust outlet of housing

$\begin{array}{lllllllll}\mathrm{S} & \mathrm{ST} & \mathrm{S}+ & \mathrm{S} & \mathrm{VS} & \mathrm{S} & \mathrm{S}+ & \mathrm{S}+ & \mathrm{T}+\end{array}$

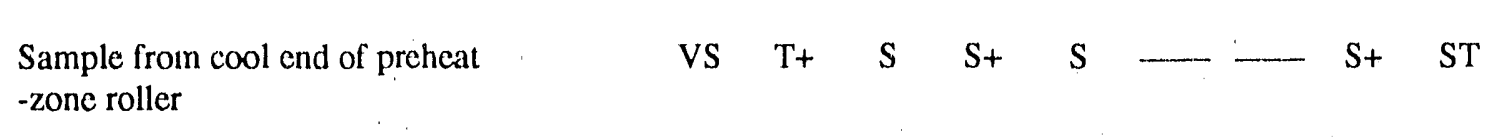

Sample from hot-zone mortar (outer layer found on fire brick)

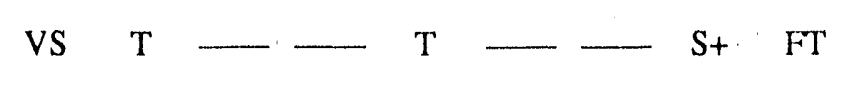

Sample from hot-zone mortar

(outer layer found on fire brick)

VS $\quad \mathrm{T}-\mathrm{T}+-\mathrm{FT} \quad \mathrm{S}+\mathrm{T}+$

Sample from cool end of hot-zone roller

$\begin{array}{llll}V S T T & \mathrm{FT} & \mathrm{ST}-\mathrm{VF}+\mathrm{VS} \quad \mathrm{ST}\end{array}$

Grey "icicle hanging from exhaust inlet"

$S \quad S-S T S T V+T+S T$ T

Green powder in exhaust outlet section

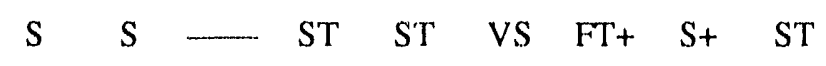

Grey-grcen residue found 4-in.

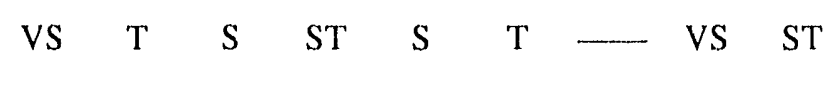


- Alkali compounds in trace quantities in the organic binder used in product (substrate).

- A defloccullent similar to Calgon (sodium hexameta-phosphate).

- A material that should not have passed thru the kiln.

- A material contained in the refractory setter used for the transport of ware through the kiln.

- Trace alkali in the alumina substrate being sintered.

Because the recuperators failed again, in another 15 months, the sources considered to be start up related were eliminated. Analysis of the organic binder showed that it does decompose and vaporize gases containing large amounts of alkali and phosphate. Further investigation showed that the quantity of product fired in the furnace each month produces a few pounds of alkali per month. The recuperator acts as a collector, as the vapor condenses on the cooler surface of the recuperator. Reactions then proceed, as the crystalline ceramic is converted to a glassy material. Figure 8 shows a phase diagram illustrating how the addition of sodium to cordierite reduces the melting temperature of cordierite. From right to left in the cordierite phase field, as the amount of sodium increases, the melting point steadily decreases. This diagram does not represent the phases present in the corroding core, but the diagram gives the general trend of the reaction of cordierite with an alkali.

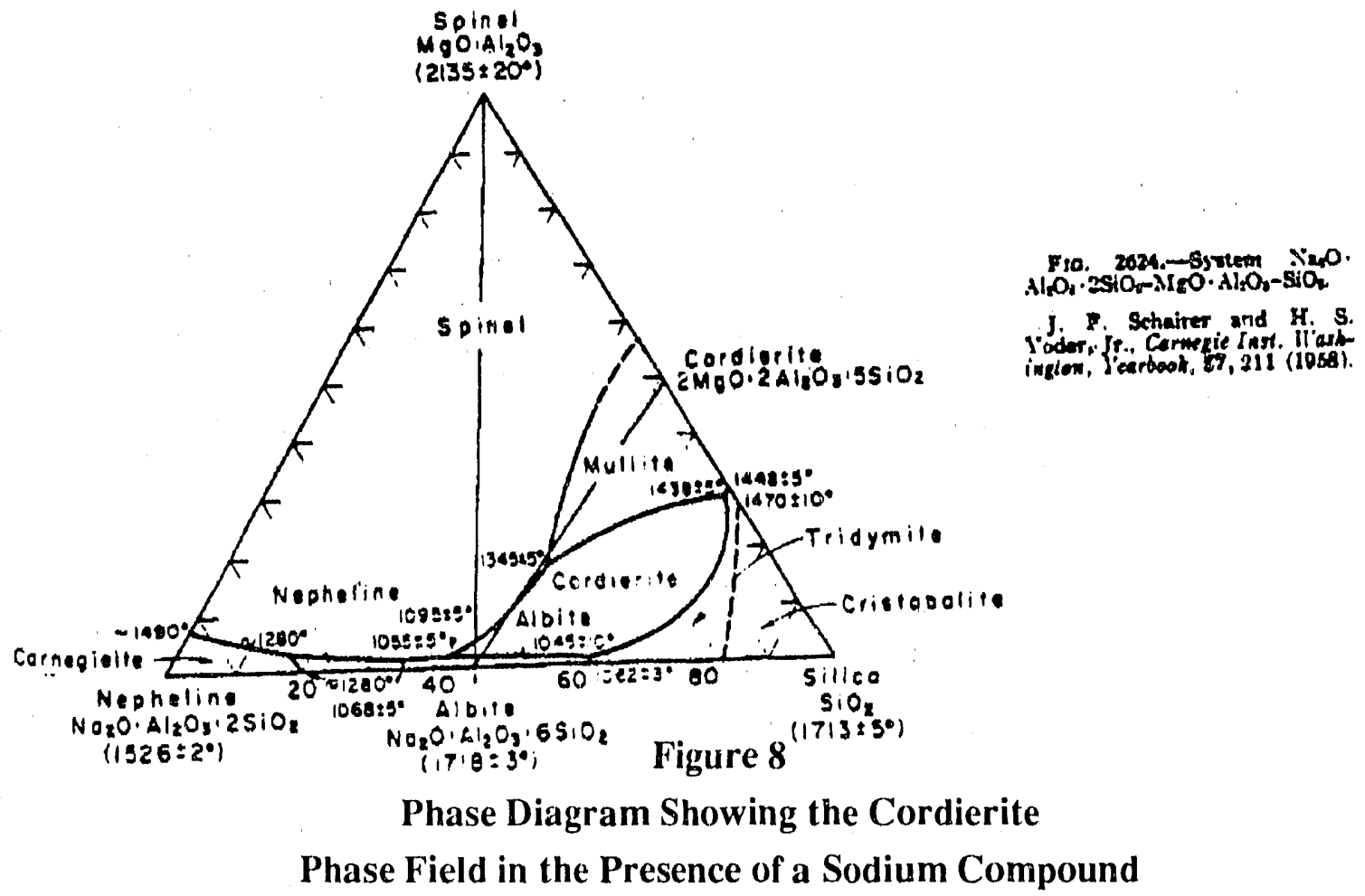


The removal of recuperators prior to complete failure produced identical results in terms of corrosive analysis. Softening of the outer extremities of the exhaust inlet face was apparent, however the degradation was limited to the "dead zone" of the exhaust inlet. Once the reaction proceeds to the area where combustion air flow exists dramatic increases in leakage rates occur rapidly.

Scaling of the ceramic was also observed during the post mortem analysis. A 0.002-in. thick section would separate from the matrix after exposure to the alkali. The newly exposed surface would then be exposed. Another scale section would form, then separate. The wall thickness of the ceramic recuperator matrix is only 0.050 -in. This process helps to explain how the base of the ceramic becomes filled in (Figure 6). The continuing spalling, coupled with continuous contamination and exposure eventually leads to the blockage illustrated.

Recommendations made to maximize recuperator life were the reduction of exhaust inlet temperatures to $2000^{\circ} \mathrm{F}$ or below, and the substitution of organics with a lower level of alkali. Life cycles are currently approximately $2-2.5$ years.

\subsection{SLOT FORGE FURNACE (Dana Corporation - Lansing, Michigan)}

The slot forge furnace at Dana utilizes two $\mathrm{R} 1500$ recuperators. The exhaust gases pass directly into the recuperator mounted on the side walls of the furnace. A burner is mounted directly to the recuperator. A burner-recuperator pair is mounted on each side of the furnace, and directly oppose each other. Figure 9 shows the arrangement of the recuperator on the fiberlined furnace side wall. The hearth of the furnace is No. 2B stone (gravel).

The purpose of the gravel is to absorb any molten metal and/or scale that is generated during forge reheat operations. This practice is common on uncontrolled slot forge reheat furnaces. The operator only monitors the surface temperature of the steel (optically), and begins forging as soon as the bar obtains the required temperature $\left(2300^{\circ} \mathrm{F}\right.$ range). The furnace may operate at temperatures well above $2800^{\circ} \mathrm{F}$ in an attempt to rapidly achieve working temperatures. This process often resulted in the formation of molten steel. The recuperated furnace had a temperature limitation of $2450^{\circ} \mathrm{F}$ due to the recuperator. The gravel hearth was specified by the furnace designer to accommodate the scale created by the operation. The hearth is changed routinely (7-14 days).

Slot forge furnaces are started daily at 5:00 AM, and forging should begin within 2 hours. Exhaust gas inlet temperatures approach $2300^{\circ} \mathrm{F}$ within 3 minutes. The relatively low thermal mass of the fiber-lined furnace makes the rapid heat-up possible.

Figure 10 shows the exhaust inlet of a recuperator removed from service at Dana. The 


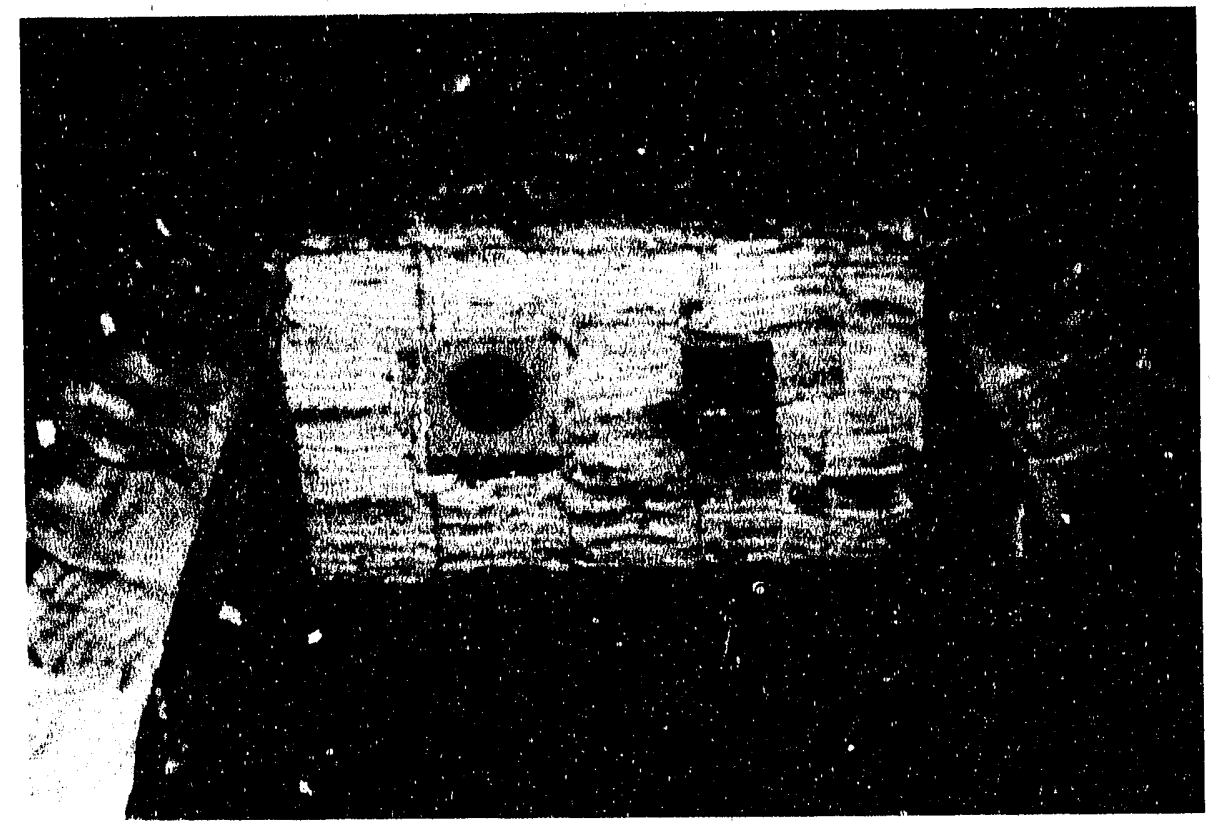

Figure 9

\section{Side Wall of Dana Slot Forge Reheat Furnace Showing Burner-Recuperator Location and Gravel Hearth (viewed with crown removed)}

matrix is covered with a black and brown coating. Preliminary indications are that iron and carbon are present.

Figure 11 shows the faces of air side and exhaust side passages located in the center of the recuperator. The arrows indicate the fluid flow directions. The cracking patterns are most severe in the hottest section of the recuperator (combustion air outlet). Here the ceramic is hottest, and most likely to react with contaminants. This matrix was leaking $40 \%$ when removed from service, but preheat air temperatures were still in the $1100^{\circ} \mathrm{F}$ range. Complete failure (inability to reheat the load in the required time) would have occurred shortly.

The spectrographic analysis showed the presence of sodium, potassium and iron in concentrations greater than $5 \%$. The source for the sodium was determined to be the gravel. The source for the iron was the steel scale formed during forge reheating. Gravel was fired at GTE to $2450^{\circ} \mathrm{F}$ for a 24 -h period at $10 \%$ excess air conditions. Figure 12 shows the fused residue of the gravel. Table 12 contrasts the compositions of the raw gravel and fired gravel. The table shows that the alkali fluxes are present in both the raw and fired gravel, but not in the same quantities as in the raw gravel. At furnace temperatures, these elements volatilize from the gravel and deposit (condense) and react with the cordierite. 


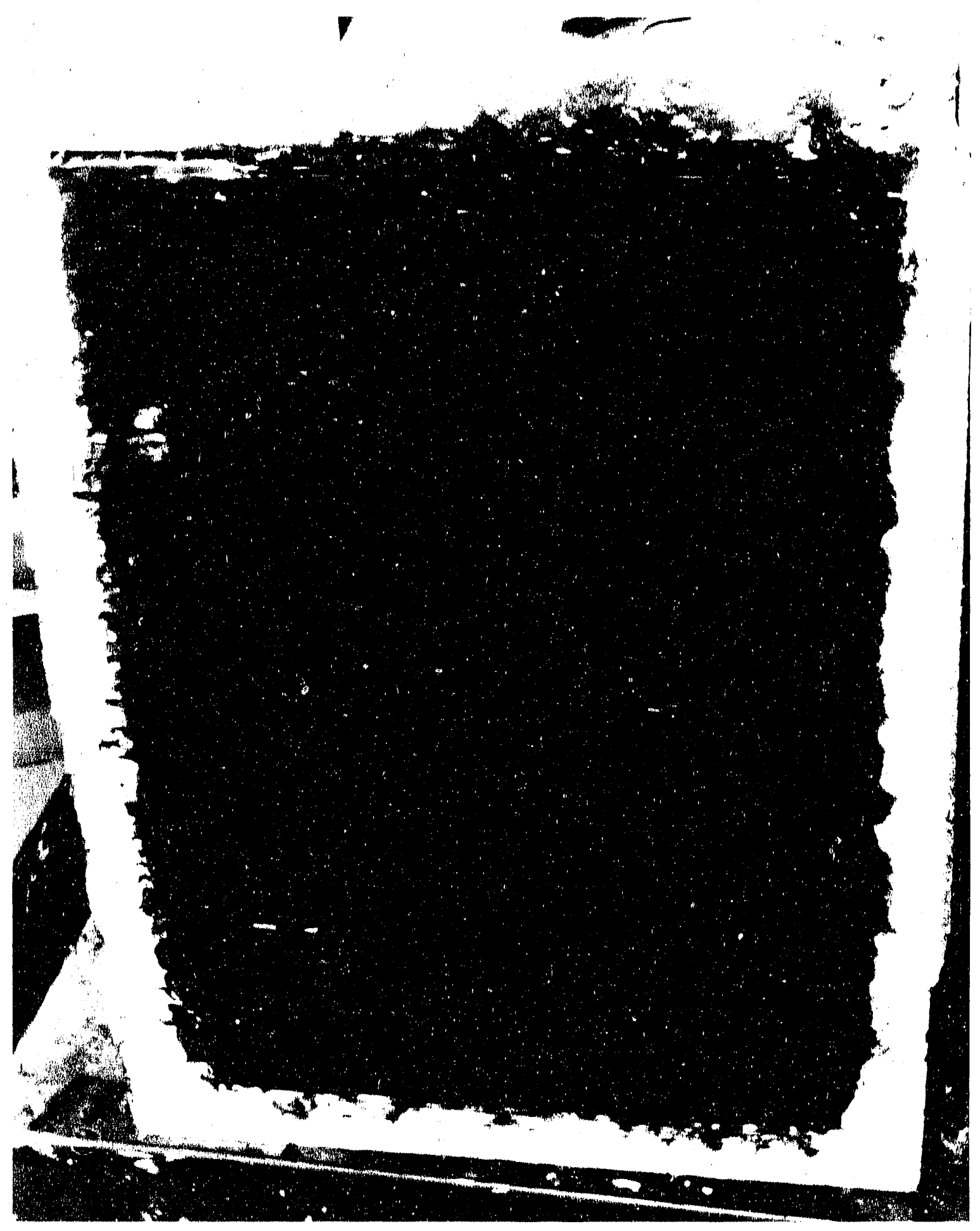

Figure 10

R1500 Recuperator Exhaust Inlet After 5 Months of Operation on Dana's Slot Forge Reheat Furnace 

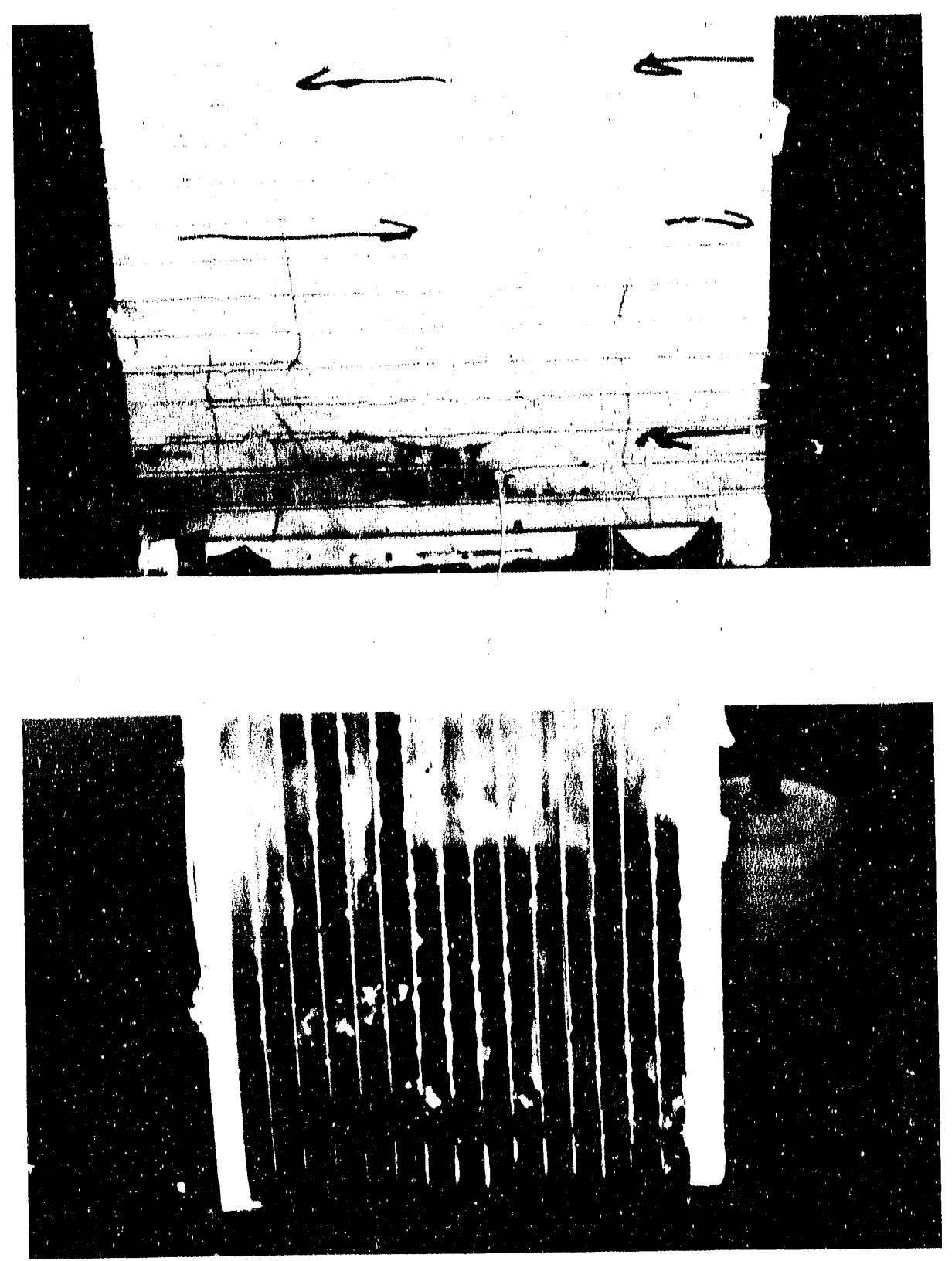

Figure 11

Air-Side and Exhaust-Side Passage

Extracted from the Center Section of a GTE Recuperator Removed from a Dana Corporation Slot Forge Reheat Furnace 


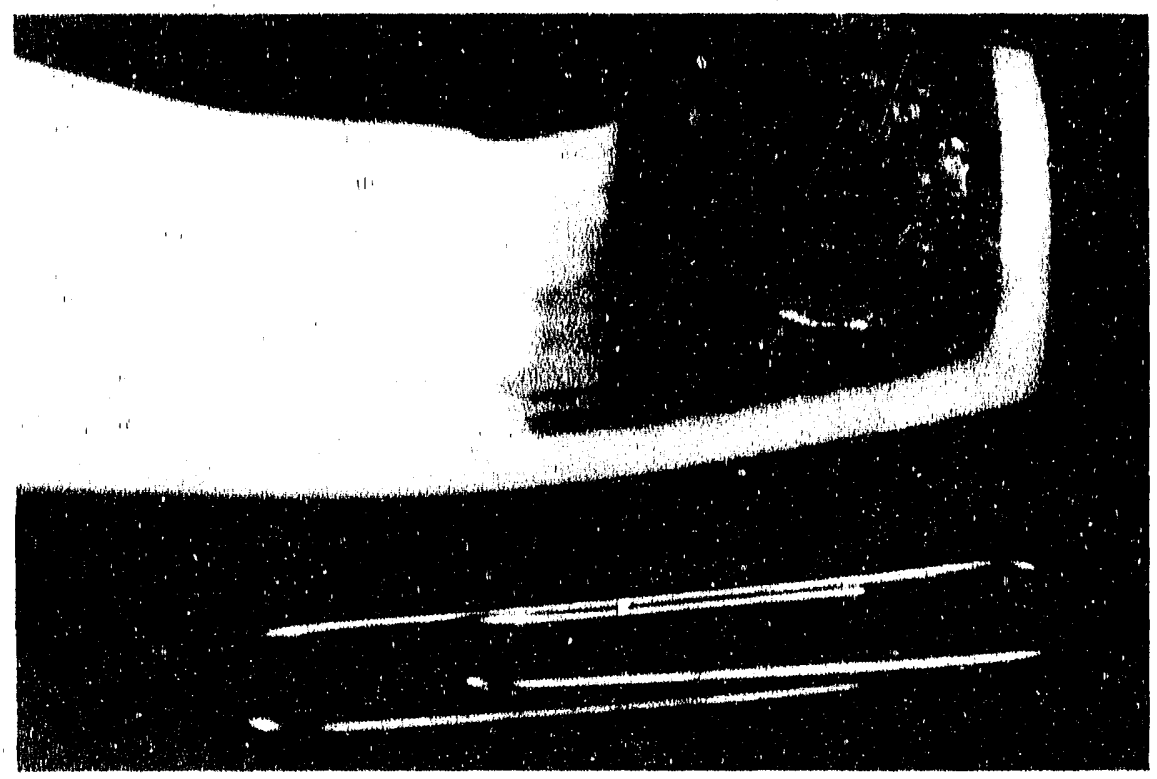

Figure 12

Fused Gravel Removed from a Dana Corporation

Slot Forge Reheat Furnace After a 24-h soak at $2450^{\circ} \mathrm{F}$

Table 12

Spectrographic Qualitative Analysis

of Fired and Unfired Gravel from Dana's Slot Forge Furnace

\begin{tabular}{lccccccccccc}
\hline Sample Description & Al & Ca & Fe & K & Li & Mg & Mn & Na & Pb & Si \\
\hline Raw Gravel & T & VS & ST & ST & FT + & VS & ST & T & VF+ & ST \\
\hline Gravel fired to 2450 oF $(24-h)$ & T & VS & ST & VF+ & VF+ & VS & T+ & VF & & & ST
\end{tabular}

The recommendation to replace the gravel refractory hearth with a high temperature castable refractory increased the life cycle from 4 weeks to 6-8 months. This increase made the recuperator life cycle acceptable from an economic perspective. Another design flaw was the placement of the recuperator on the side of the furnace. The exhaust gases traveled horizontally through the recuperator. A design modification was made that called for an 
exhaust flue to be mounted on the furnace side wall. The flue's function was to transition the exhaust flow so that it passed vertically through the recuperator. This eliminated the metallic scale that often stuck to the side of the exhaust inlet of the recuperator, as the scale would settle out in the right angle section of the exhaust flue.

\subsection{LEAD WIRE ANNEALING FURNACE (Am. Spring Wire - Cleveland, Ohio)}

The furnace at American Spring Wire Company has a R 1500 recuperator on each of two zones. Each recuperator is connected to four hot-air burners. The lead bath temperature is controlled automatically by adjusting the mass flow rate of the combustion air to each recuperator. The high fire input is adjusted to a $30 \%$ excess air rate. A spring loaded gas pressure regulator is loaded by an impulse line from the cold side of the recuperator. The regulator is adjusted to trim gas flow at a rate greater than the reduction in air flow. The net result is that the low fire input rate ( $4: 1$ flow turndown) operates at a $100 \%$ excess air firing rate. This control scheme offers a thermal turndown of greater than 20:1. The variable excess air mode of temperature control insures that thermal uniformity in the combustion chamber is maximized (maximum convection). The thermal input rate during annealing operations approaches the maximum thermal input rate of 2.5 million Btu/h, at $30 \%$ excess air.

The exhaust outlet from each recuperator is connected to a common manifold, and attached to a high-temperature exhaust fan. Exhaust flow through each recuperator unit is constant, however, the combustion air flow rate through each unit varies according to demand. The zone 2 control sensor measures the lead melt temperature at the exit end of the wire bath. The heat required to maintain the zone 2 temperature is less than that required by the zone 1 unit. The zone 1 combustion system must supply energy to recover the losses imparted when the ambient wire enters the retort. This recuperator generally operates at or near its high-fire rating

Actual measurements show the exhaust inlet temperatures to be in the 2200 to $2300^{\circ} \mathrm{F}$ range. If we look at the combustion air flow entering each recuperator as cooling air, it becomes apparent that the unit with the greater combustion air mass flow rate will operate with the lowest mean temperature. The unbalanced combustion air flow makes the zone 2 recuperator run hotter at American Spring Wire. The fact that the preheated air temperatures from the zone 1 recuperator are cooler by 200 to 400$)^{\circ} \mathrm{F}$ confirrns that the recuperators have different mean temperatures as a result of the mass flow imbalance. The zone 2 recuperator failed, while the zone 1 recuperator did not. The exhaust inlet of the zone 2 unit has melting on $50 \%$ of the face while the zone one unit had only a few areas that were melted. Figure 13 shows the exhaust inlet of the zone 2 recuperator. 


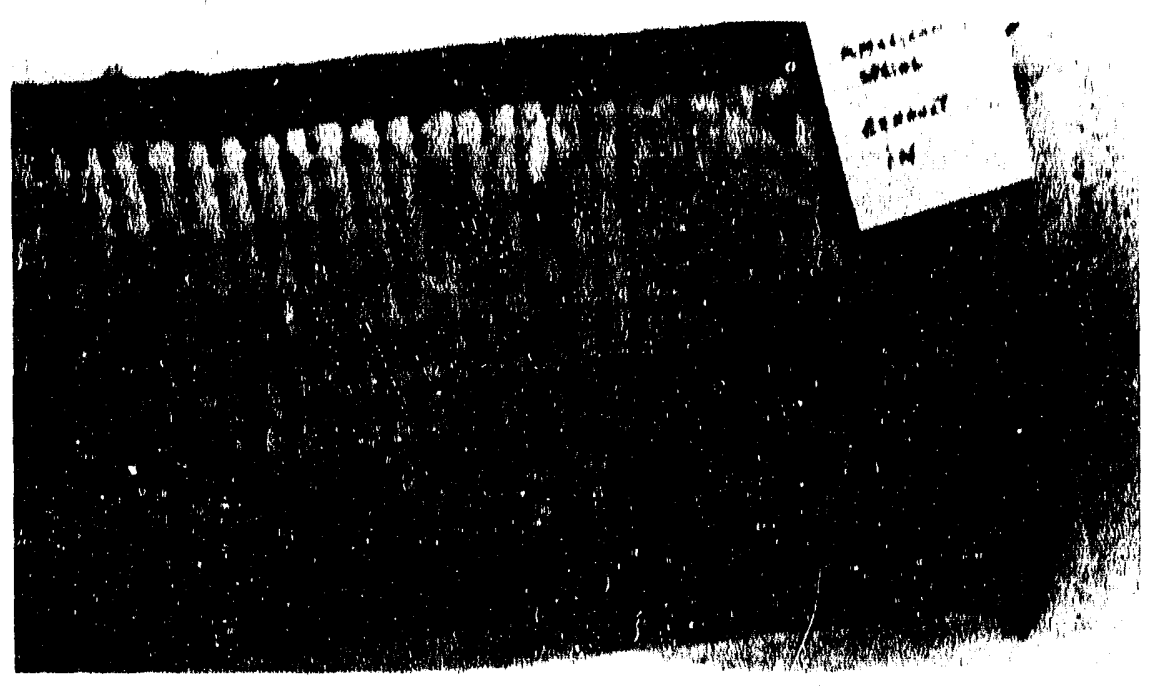

Figure 13

\section{Exhaust Inlet of R1500 Recuperator Removed from Lead Wire Annealing Furnace at American Spring Wire Company}

Table 13 shows the results of a spectrographic analysis of various samples taken from American Spring Wire's annealing furnace. "Coke breeze" is the material on the top of the lead bath. Recuperator 2 was removed due to failure after 6 months of operation, and was replaced by recuperator 3 . After a second failure ( 3 months of operation), both recuperators failed and were replaced (recuperator 1 and 3). This failure occured soon after the lead pot was replaced (it failed). Recuperator 4 and 5 were operated for 1 year and removed after unit 5 failed (zone 2). Unit 5 was in excellent condition and was inspected and placed back on the furnace.

Both alkali and lead played a role in the failure of the recuperators at American Spring Wire (ASW). Lead enters the exhaust gas stream after it vaporizes in the combustion chamber. Molten lead from the exit portion of the pot (carried by the wire) drips onto the hot refractory, then migrates through the refractory and into the chamber. Another method that the lead enters the recuperator can be due to the leaking of a ruptured pot. The source of the alkali is believed to be from the castable refractory or the fiber board insulation used on the furnace. .

A test was run on GTE's test furnace to simulate the conditions at American Spring Wire. A 200 gram sample of NaOry was placed directly below the exhaust inlet of an R150) recuperator. The furnace was operated for $24-\mathrm{h}$ at $2500^{\circ} \mathrm{F}$. Flow rates and stoichiometric conditions were selected to simulate operation at ASW. The surface of the matrix was similar to that shown in Figure 13 (Zone 2 from ASW). This confirms the effect of the alkali found on all the recuperators that have failed due to corrosive attack. 
on all the recuperators that have falled due to corrosive attack.

'Table 13

Spectrographic Qualitative Analysis of

Samples from American Spring Wire Company

\begin{tabular}{llllllllllllll}
\hline Sample Description & Al & Cr & K & LI & Na & P & Pb & Si & Ti \\
\hline $\begin{array}{l}\text { Mutertal from the exhuust inlol } \\
\text { of cube } 2, \text { Zonc } 2 \text { (A) }\end{array}$ & S'T't & ST' & VS & S+ & VS & VS & VS & VS & ST \\
\hline
\end{tabular}

Material from center of exhaust cells

ol cube 1, Zone 1 (J)

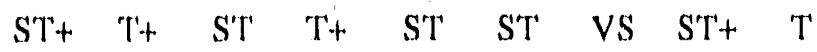

Material from the exhaust inlet

$\begin{array}{lllllllll}\text { VS } & \text { T't } & S & S T & S & S & \text { VS } & \text { VS } & S^{\prime} T '+\end{array}$

of cube 3, zone 2 (F)

Material from center of exhaust cells

of cube 3, zone $2(\mathrm{H})$

ST $\quad$ T ST FT' $\quad S \quad S+$ VS $\quad S+$ ST

\begin{tabular}{|c|c|c|c|c|c|c|c|c|c|}
\hline Sample of lead from annealer (L) & $\mathrm{FT}$ & VF+ & $\mathrm{VF}+$ & $-\ldots$ & $\mathrm{VF+}$ & $-\ldots$ & VS & $\mathrm{VF}$ & VF \\
\hline $\begin{array}{l}\text { Sample of "coke brece" (M) } \\
\text { (iron and zinc concentration is ST+ }\end{array}$ & ST't & $\mathrm{FT}$ & $\mathrm{T}$ & VF+ & $\mathrm{FT}^{+}$ & - & ST & $s$ & $\mathrm{ST}^{\prime}$ \\
\hline $\begin{array}{l}\text { Material from center of exhaust cells } \\
\text { of cube } 4 \text {, zone } 1\end{array}$ & ST't+ & STt & $S^{\prime} T^{\prime}$ & $S T$ & 'T' & $\mathrm{S}+$ & $S+$ & $\mathrm{T}$ & ST' \\
\hline
\end{tabular}

Life cycles were extended to over 1 year by implementing the suggestions based upon results of the data shown in Table 13 (unit 4 and 5). These procedures were implemented when possible at American Spring Wire:

- Run the combustion air flow rates constant, and control temperature via regulation of the gas flow rate only. This will tend to balance the mass flow rates through the recuperators. Expected results are a more uniform lifecycle for the zone 1 and zone 2 recuperator, and a corresponding reduction in maintenance costs.

- Burn the refiactory out with the exhaust bypassing the recuperators after a pot failure. This will volutilize any lead contained in the refractory and avoid 
contumination of the recuperators. Additionally any alkall that vaporizes from the castabie refractory will avoid the recuperator.

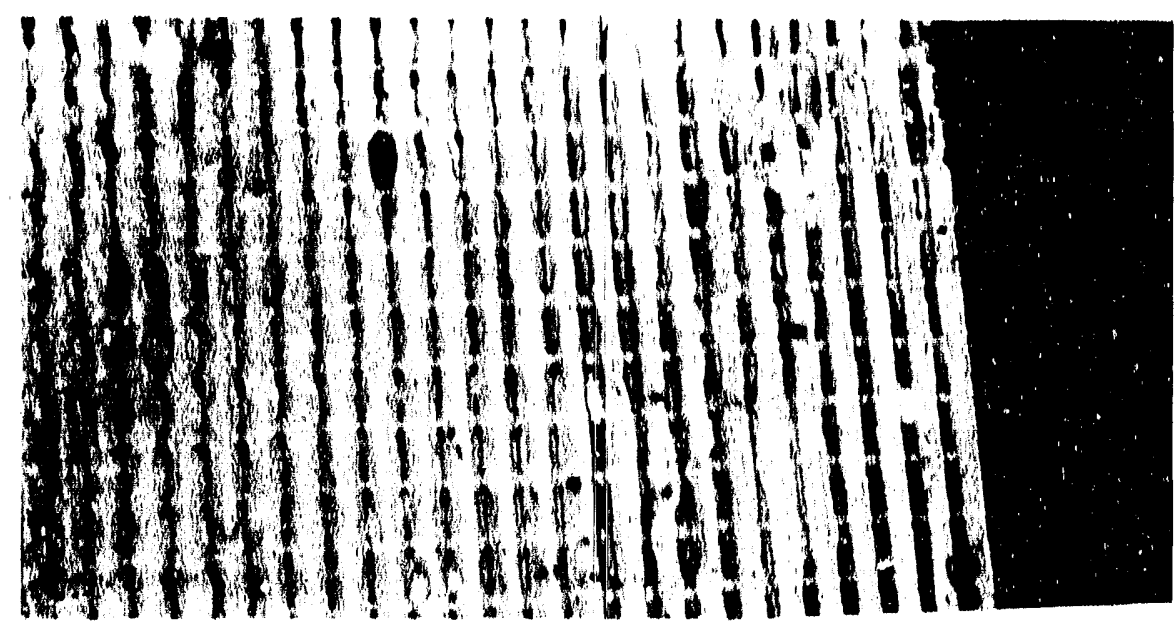

Figure 14

\section{Exhaust Inlet of R1500 Recuperator Exposed to 200-g of NaOH at 2500" $\mathrm{F}$ for 24-h on GTE's Recuperator Test Furnace.}

\section{CONCLUSIONS AND RECOMMENDATIONS}

The following conclusions may be drawn from GTE's experience with the ceramic recuperator.

- The thrust of the applications appear to be in the metal processing industries. This focus appears to be the correct one in view of the number of furnaces in these industries and potential for sales of their recuperators.

- The GTE ceramic recuperator is a success story as attested by the fact that, out of the 561 units installed on 165 new or retrofitted furnaces in 89 United States and Canadian plants, 405 or $72 \%$ are currently operating, while 117 or $21 \%$ are not in use either because of failure, poor performance, or plant shutdown. The status of the rest is unknown because those plants could not be contacted either because they declared bankruptcy or were taken over by other companies.

- The combined energy savings from the 405 units presently operating may be estimated at about 0.5 trillion Btu annually, In addition to energy savings productivity increases and material savings have also benefited the industrial users. 
- The recuperators were installed on furnaces operating from 1400 to $2500^{\circ} \mathrm{F}$ and prehented air temperatures varied from 600 to $1300^{\circ} \mathrm{F}$. Of those recuperators installed on furnaces operating at $20000^{\circ} \mathrm{F}$ and below, $87 \%$ are currently operating, while of those installed on furnaces operating at greater than $2000^{\circ} \mathrm{F}$, only $57 \%$ are currently operating.

- Of the three sizes of recuperators installed, $89 \%$ of the 10 in.cube units, $77 \%$ of the 12 in. cube units, and only $56 \%$ of the large units are presently operating. This fact is not just coincidental, and it is possible that the larger units are more severely stressed in operation. Another reason for the higher failure rate on the large units may relate to the extrusion and firing of the raw ceramic during recuperator production.

- Four types of problems have been experienced since the initial DOE project, two of which relate to the recuperated system and two to the specific application. The system-related problems were experienced initially and involved inadequate hotair burners and air:fuel satio controls. These were corrected by the burner manufacturers and GTE, and the current burners and control systems are operating effectively.

- The recuperator is a plate-fin unit that is very compact, with plate spacings as small as 0.125 -in. It therefore should be used in clean exhaust environments without particulates that could plug the recuperator. The other problem, plugging and corrosive attack by alkali, depend on the contaminants in the exhaust gas stream of the particular furnace.

- Plugging of the recuperator with fiber from the furnace lining can be corrected by cleaning during normal shutdown. Most plugging problems resulting from oxides deposited in the recuperator from indirect reduction furnaces could be resolved by cleaning with an air lance. Applications where vapors in the exhaust gases could condense in the recuperator, such as lead melting furnaces and glass tanks, should be avoided. Applications where the deposits are sticky and buildup occurs over time are difficult to clean without damaging the recuperator and should be avoided.

- The cordierite material of construction is susceptible to corrosion attack from 
elements such as sodium, potassium, calcium, and other alkali and alkaline earth compounds. These alkali form lower temperature melting eutectics with the cordierite and failure will result if the furnace operating temperature exceeds the softening temperature of the eutectic, which has been measured to be as low as $2100^{\circ} \mathrm{F}$ in some cases. Nonferrous metals, such as lead and zinc, have also been found to attack the cordierite material.

- Sources of alkali are fluxing agents used in aluminum remelt/reverberatory furnaces and topping compounds used on steel ingots reheated in steel reheat and forging furnaces. The operating temperatures of these furnaces range from 2200)$2400^{\circ} \mathrm{F}$, which could exceed the softening temperature of the specific eutectic formation; therefore, recuperator fallure would likely result in these applications. They should therefore be avoided.

- In marketing the ceramic recuperator, GTE has correctly targeted the metals industries. Except for two installations in the clay industry, all installations were in the metal processing industries. In these industries a total of about 48,000$)$ furnaces were identified as having potential for recuperation.

- The historical data obtained from this effort, and the information obtained by removing recuperators prior to failure confirms that failures are generally proceeding at a slow rate if trace contaminants are present in an exhaust stream. The rate is proportional to concentration and iemperature. The fact that the units generally experience an excess fuel excursion prior to complete failure is due to degradation of the matrix. The degradation of the matrix may become more extreme during the excess fuel excursion, but the failure is generally not a result of the excess-fuel condition simply caused by control system failure.

- Based on experience, industries that need to be pursued are (in order of preference):

- metal heat treating (SIC 3398)

- aluminum foundries (SIC 3361)

- steel mills (SIC 331)

- steel forging (SIC 3462), and

- $\quad$ structural clay products (SIC 325) 
- Based on the users experience, GTE should avoid the following furnace applications because of corrosive elements in the exhaust gases:

- tunnel kilns in the pottery and related industries

- ladle preheaters in ferrous and nonferrous industries

- remelt and kettle furnaces in the secondary non-ferrous industries, and

- reheat/forge furnaces processing raw ingots

- There is considerable potential in the metals industries where GTE has not retrofitted a furnace. There are about 4535 heat treat and annealing furnaces in SIC 331 that are suitable for the ceramic recuperator. In ferrous and nonferrous foundries (SIC 332 and 336) there are 5960 types of furnaces that could be retrofitted. In metal rolling and drawing operations (SIC 335), there are an estimated 4475 furnaces for smelting, holding, heating and heat treating. All of these furnace applications should be actively pursued.

\section{REFERENCES}

1. Clevelarid J.J., et al, Ceramic Heat Recuperators for Industrial Heat Recovery, Final Report, No. DOE/EC/02162, August 1980.

2. Dorazio, R.E., et al, The GTE Ceramic Recuperator for High Temperature Waste Heat Recovery, 1984 Industrial Energy Conservation Technology Conference, Houston, TX, April 15-18, 1984.

3. Ally, M.R., et al, Optimization of Multi-pass Crossflow Heat Exchangers for Waste Heat Recovery Applications, 1984 National Heat Transfer Conference, Niagara Falls, N.Y., August 5-8, 1984.

4. Ferr:, J.L., Temperature Compensated Air/Fuel Ratio Control on a Recuperated Furnace, 1983 Industrial Energy Conservation Technology Conference, Houston, TX, April 1726, 1983.

5. Gonzalez J.M., and W. J. Rebello, Furnace Controls using High Temperature Preheated Combustion Air, 1981 Industrial Energy Conservation Technology Conference, Houston, TX., April 26-29, 1981.

6. Dorazio, R. E., et al, Technology Acceleration Program for the GTE Ceramic High Temperature Recuperator. Final Report, Contract No. DE-FC01-80CS 40330, January 1983. 
7. U.S. Department of Commerce, Annual Census of Manufacturers. Fuels and Electric Energy Consumed, 1977 and 1982.

8. U.S. Department of Energy, End Use Energy Consumption Data Base.

9. U,S. Environmental Protection Agency, National Emissions Data System (NEDS) Data Base.

10. Oak Ridge Associated Universities, Industrial Energy Use Data Book, 1980.

11. Wilfert, G.L. et al, Characterization of Industrial Process Waste Heat and Input Heat Streams, Report \#PNL-4912, May 1984.

12. Canete, D.W., and J.J. Crowell, Survey of Industrial Furnace Equipment, Final Report prepared for Battelle Pacific Northwest Laboratories under Contract \# B-B4161-A-Z, December 1981. 


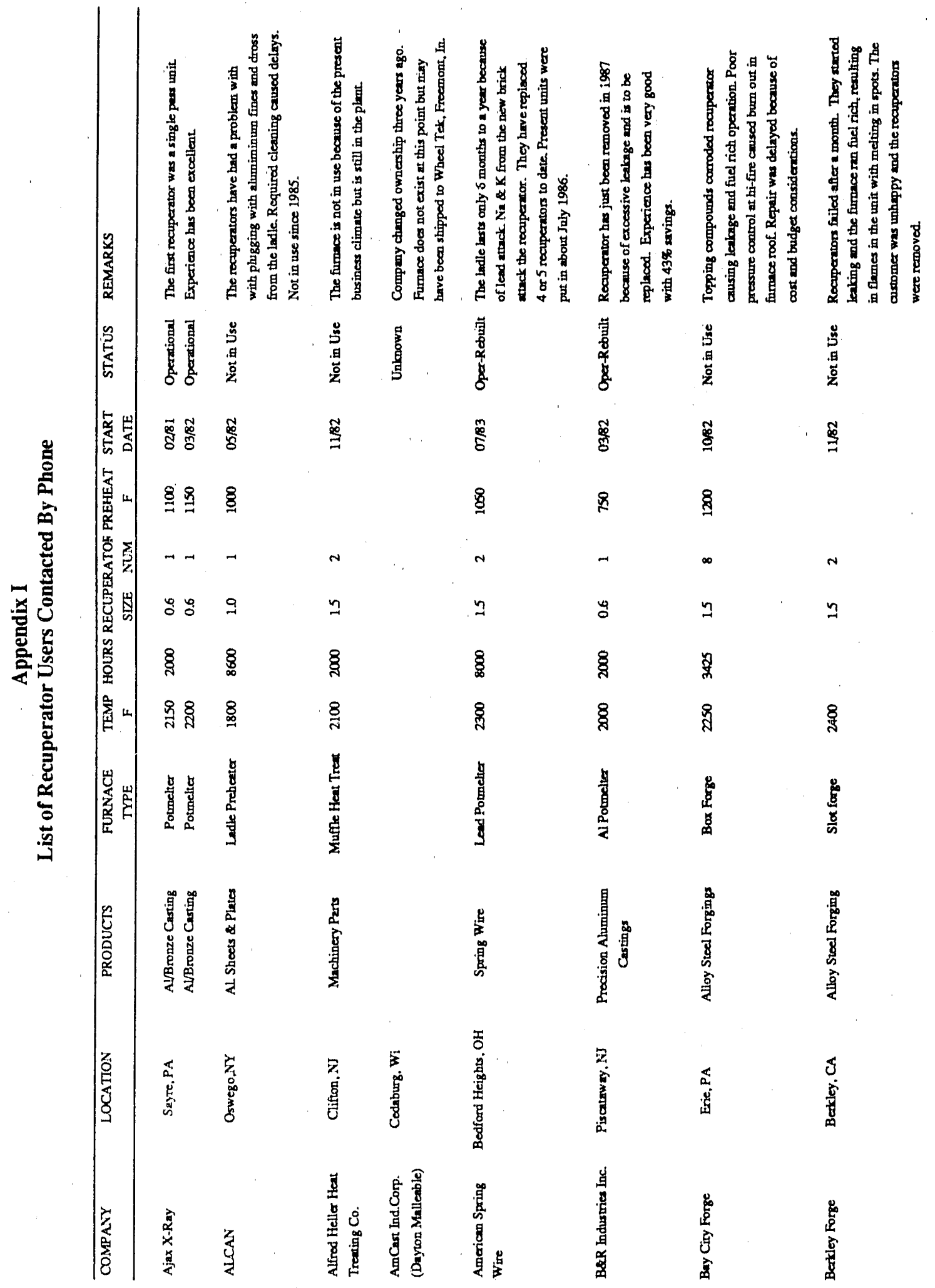




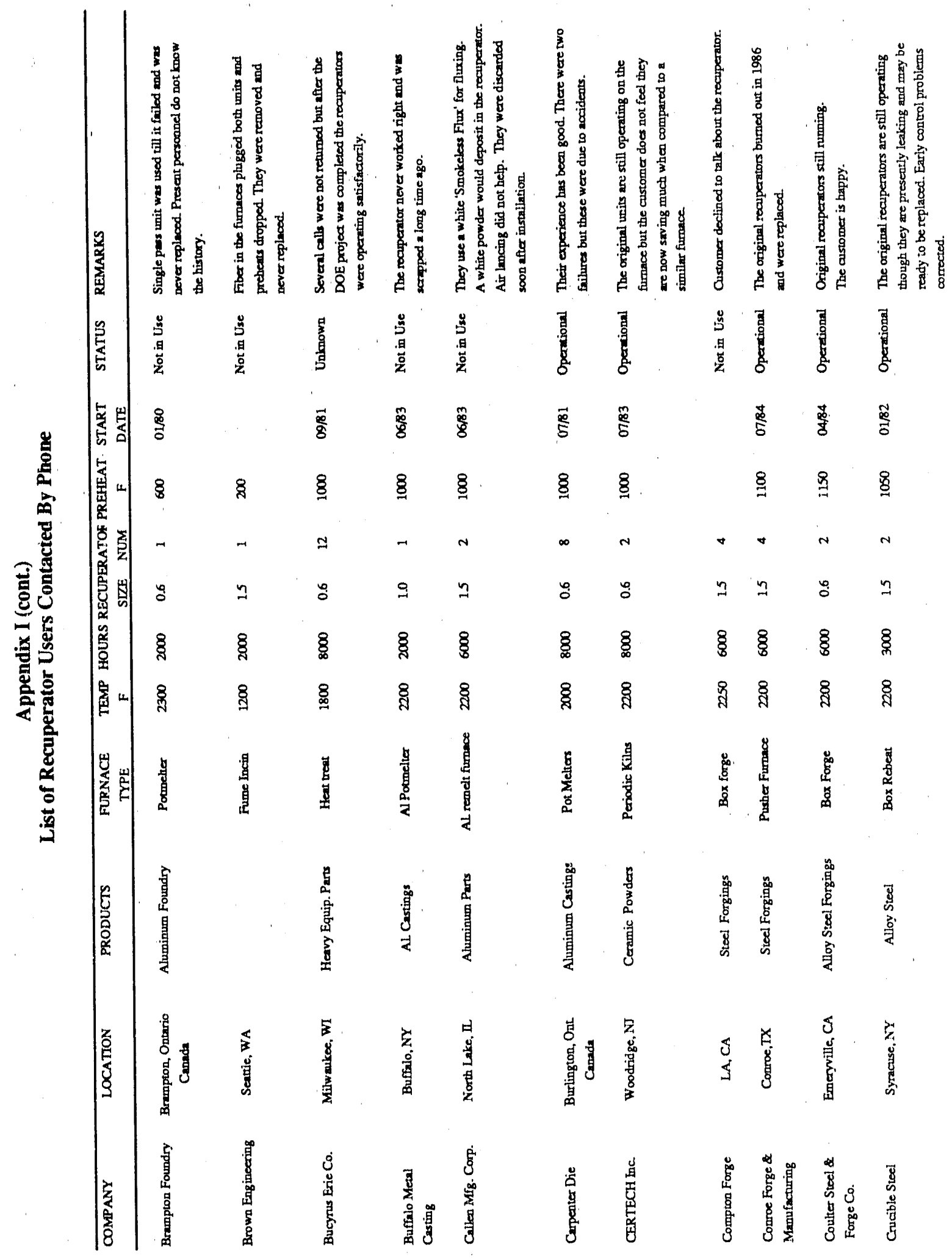




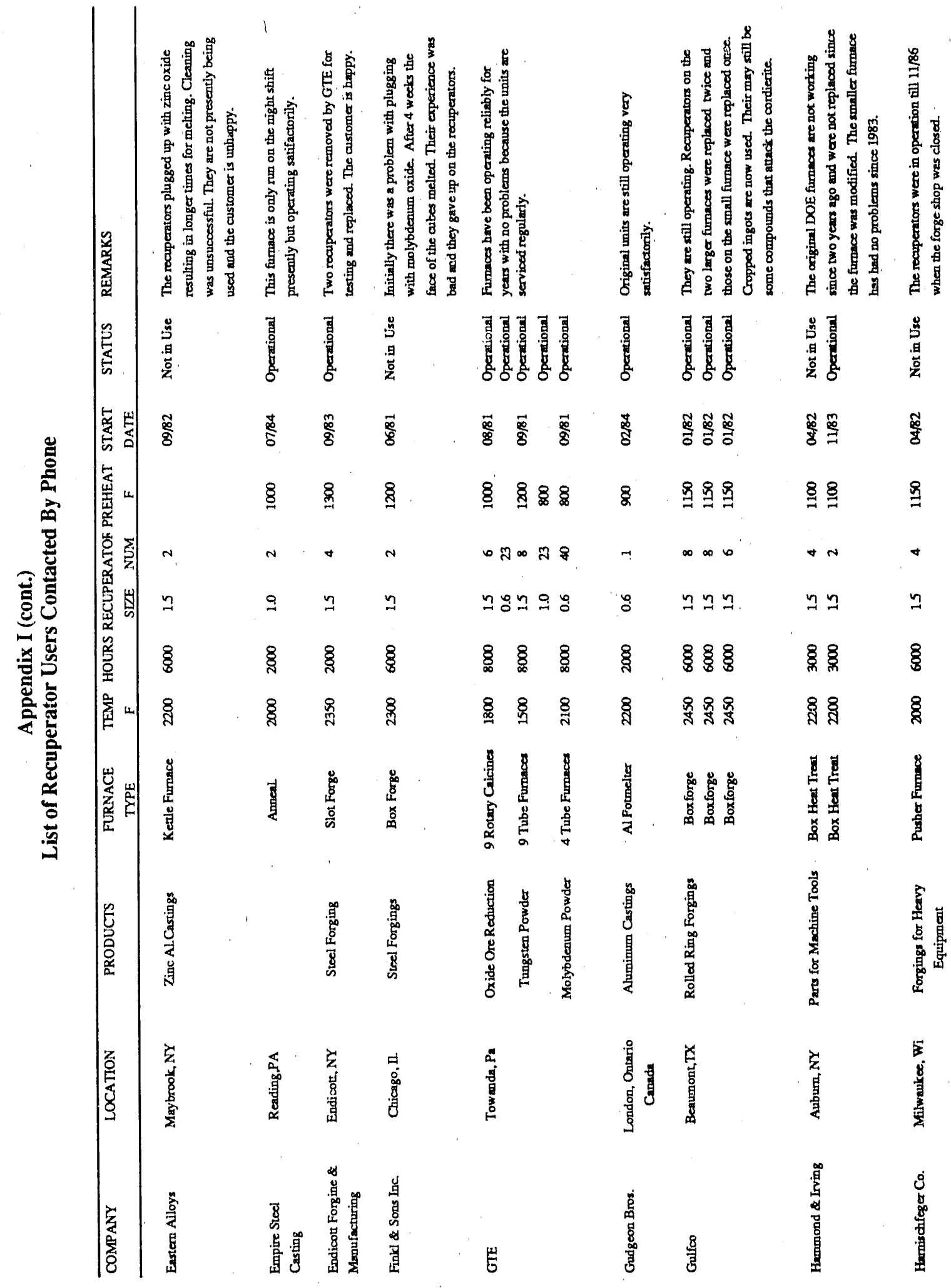




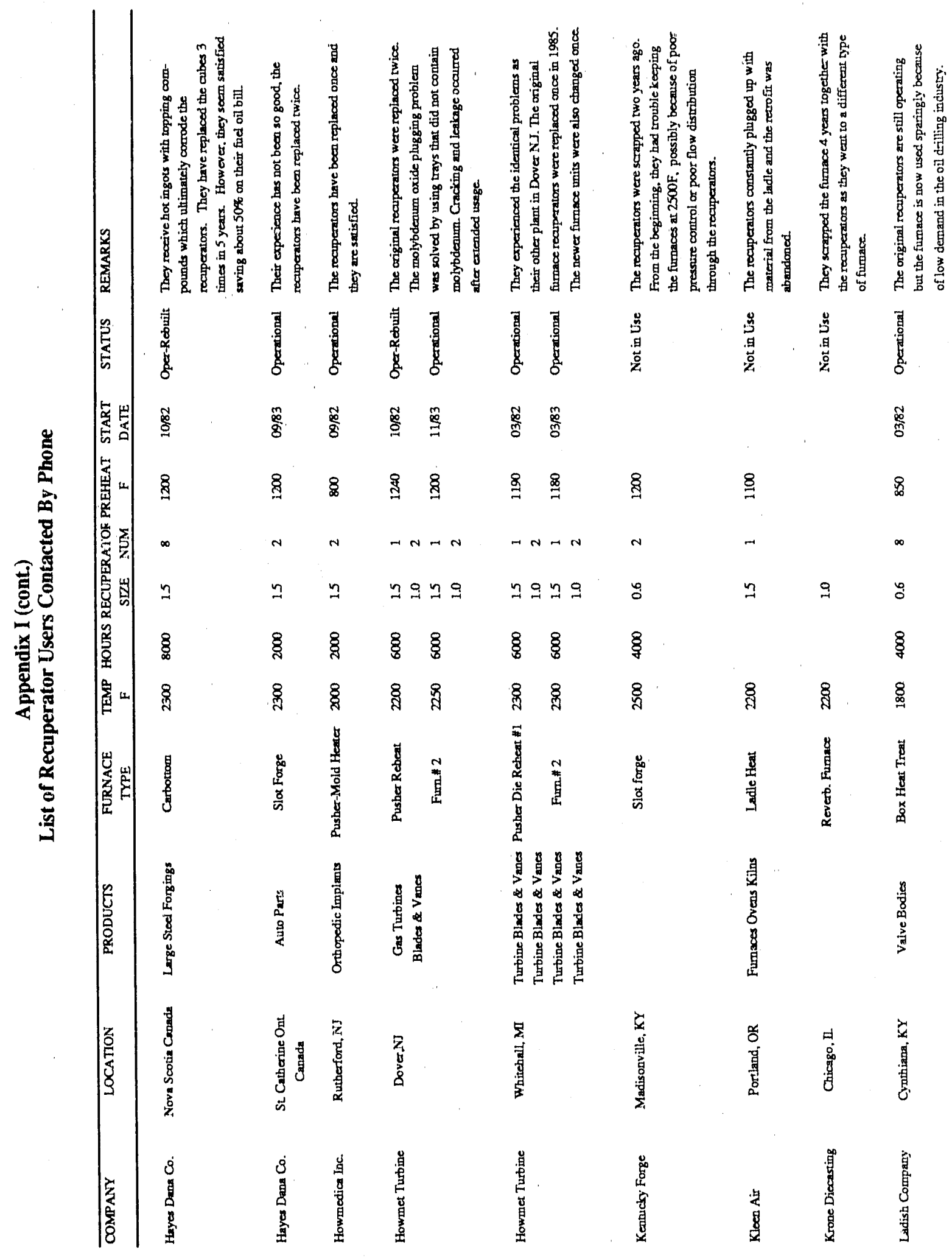




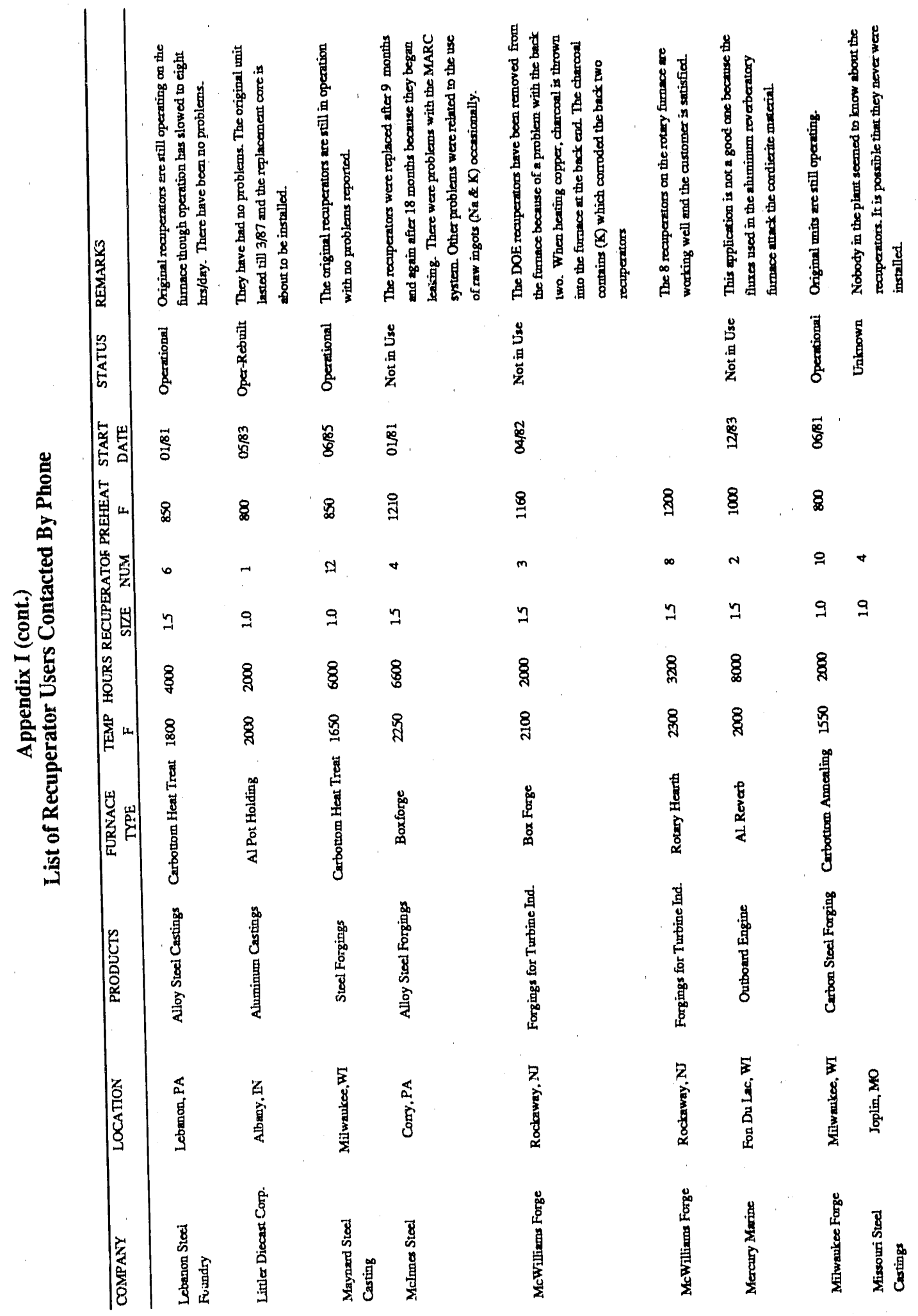




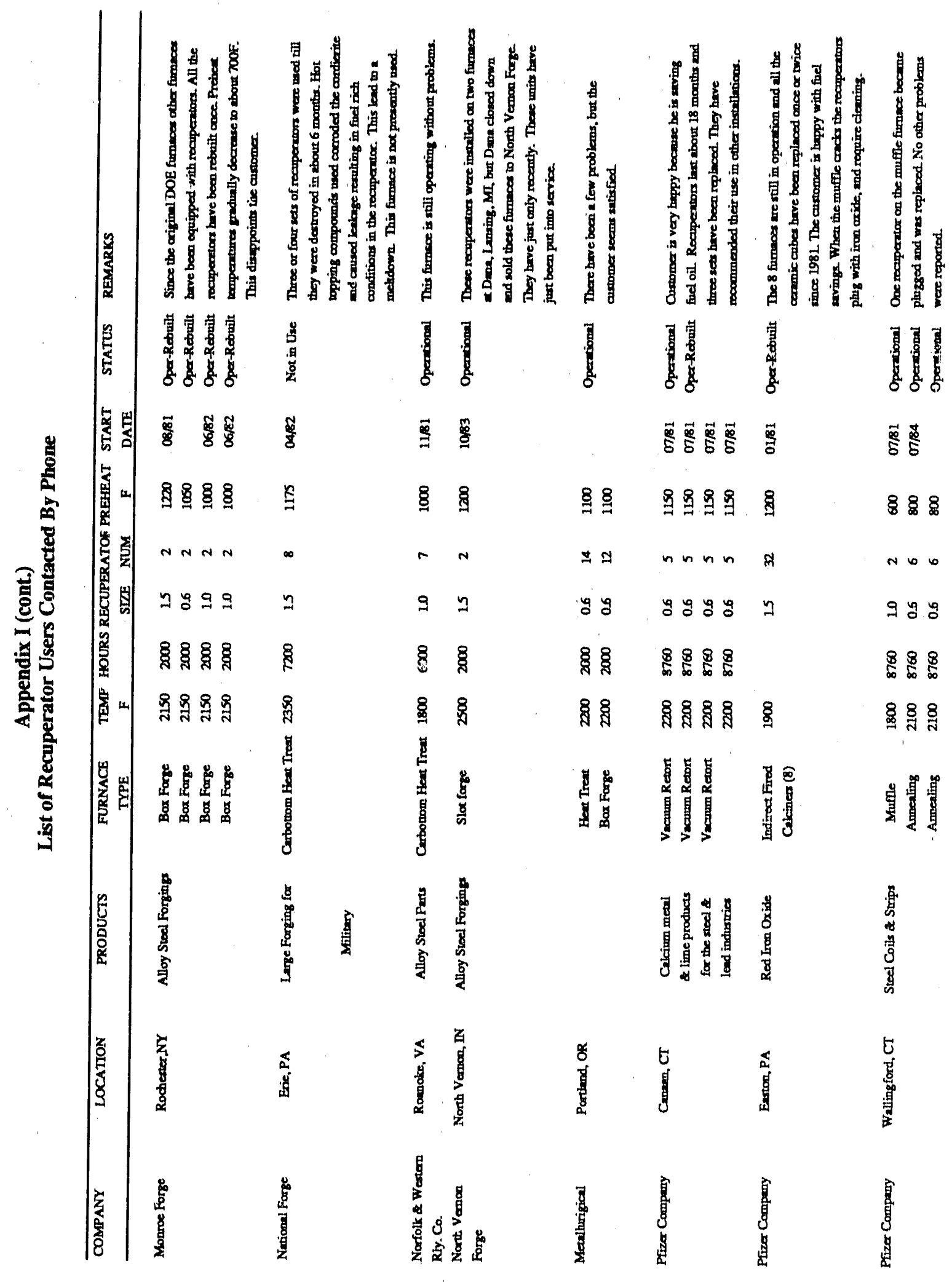




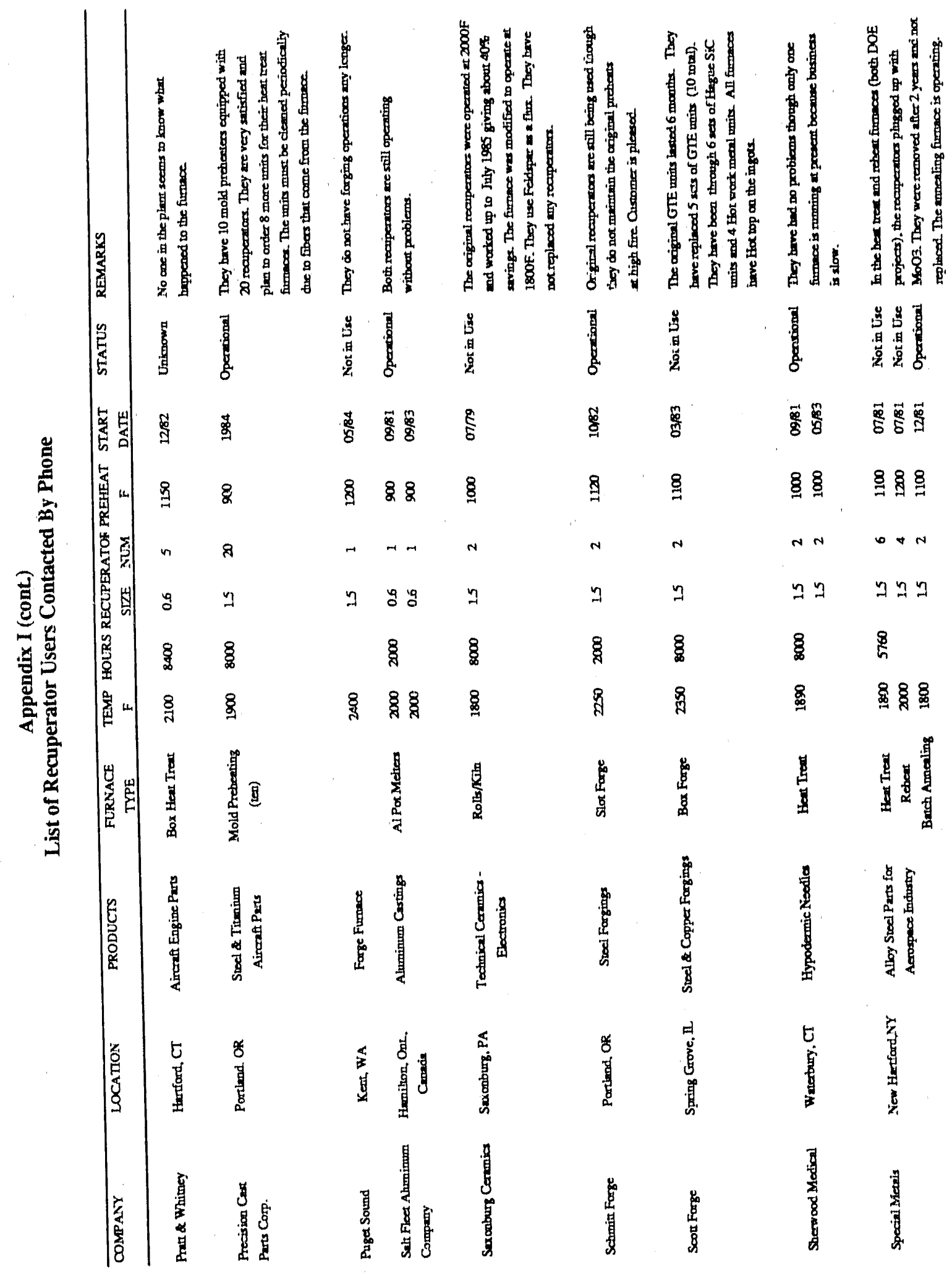




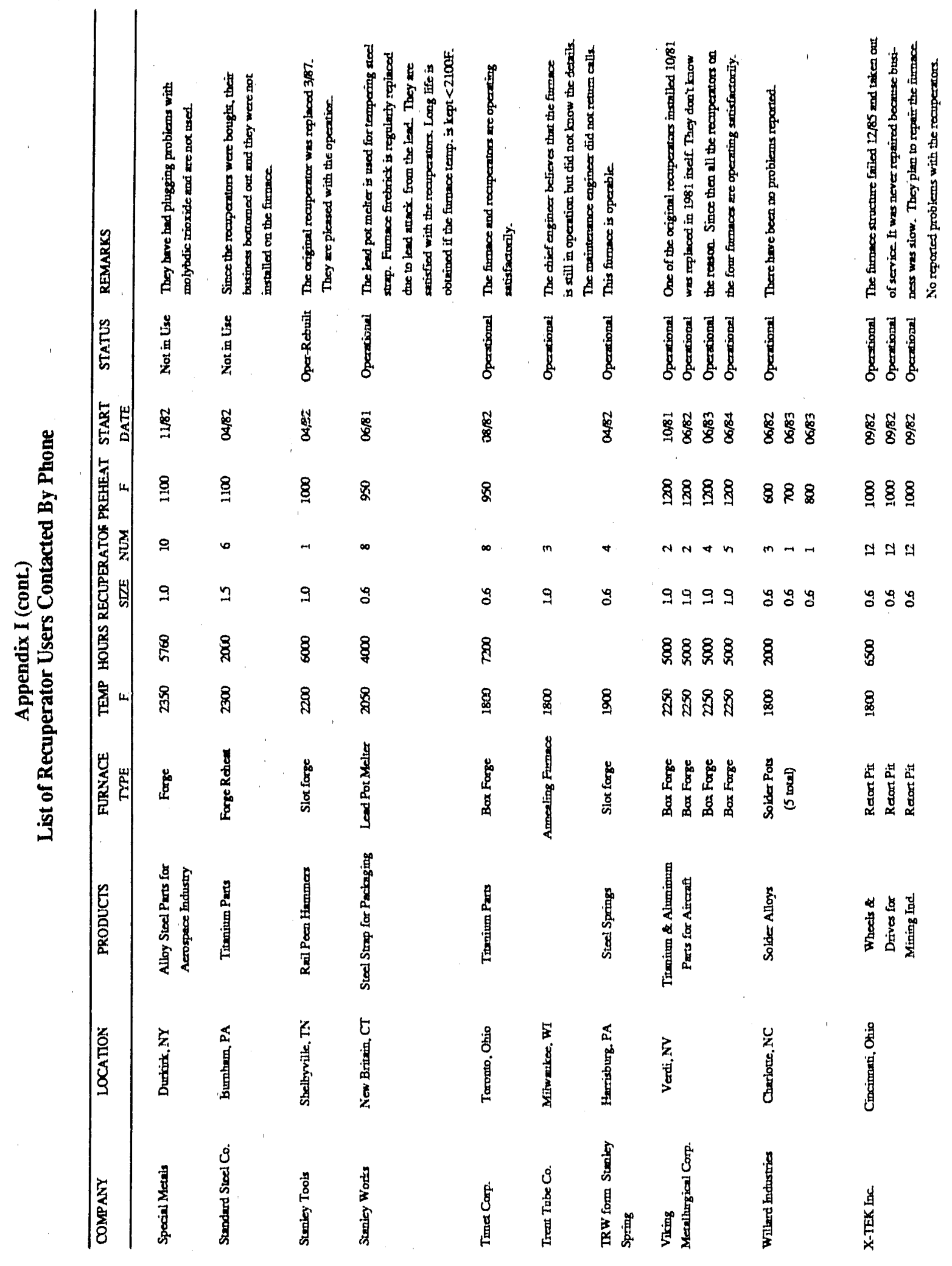




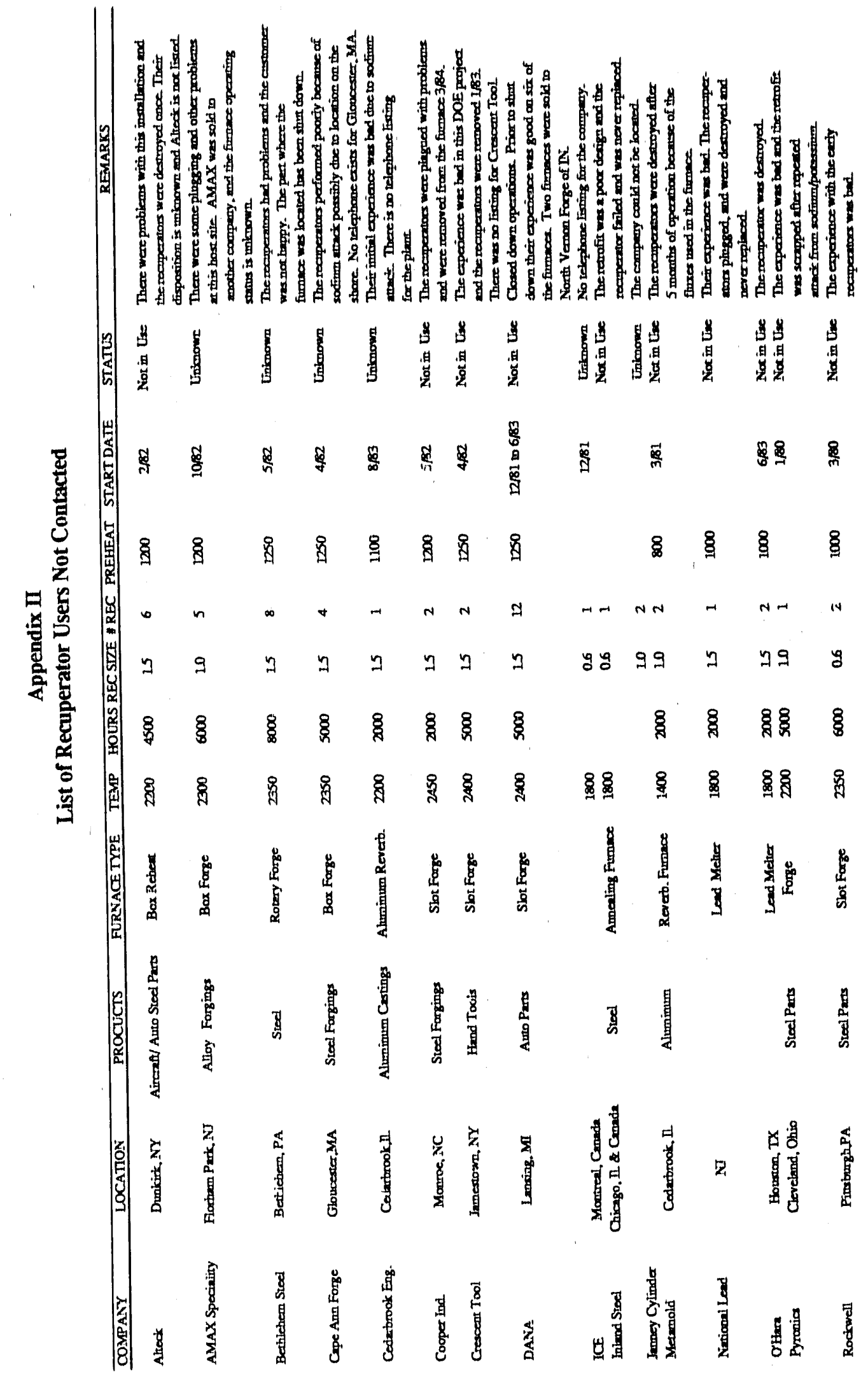


60

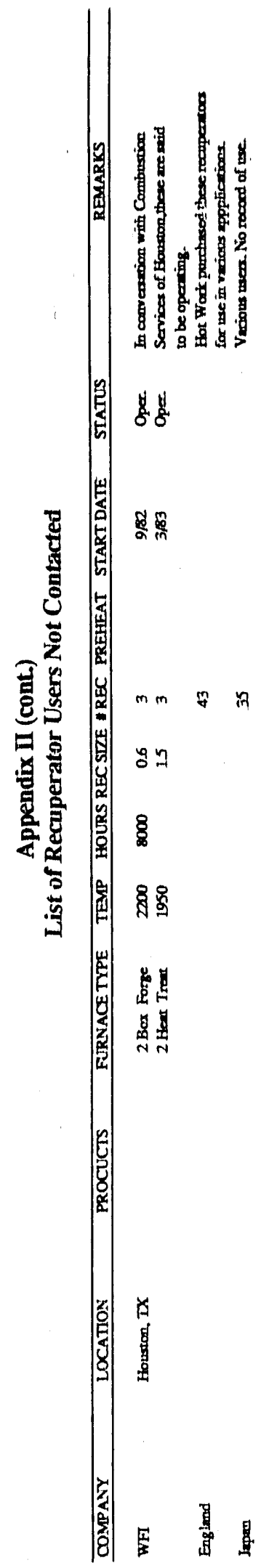



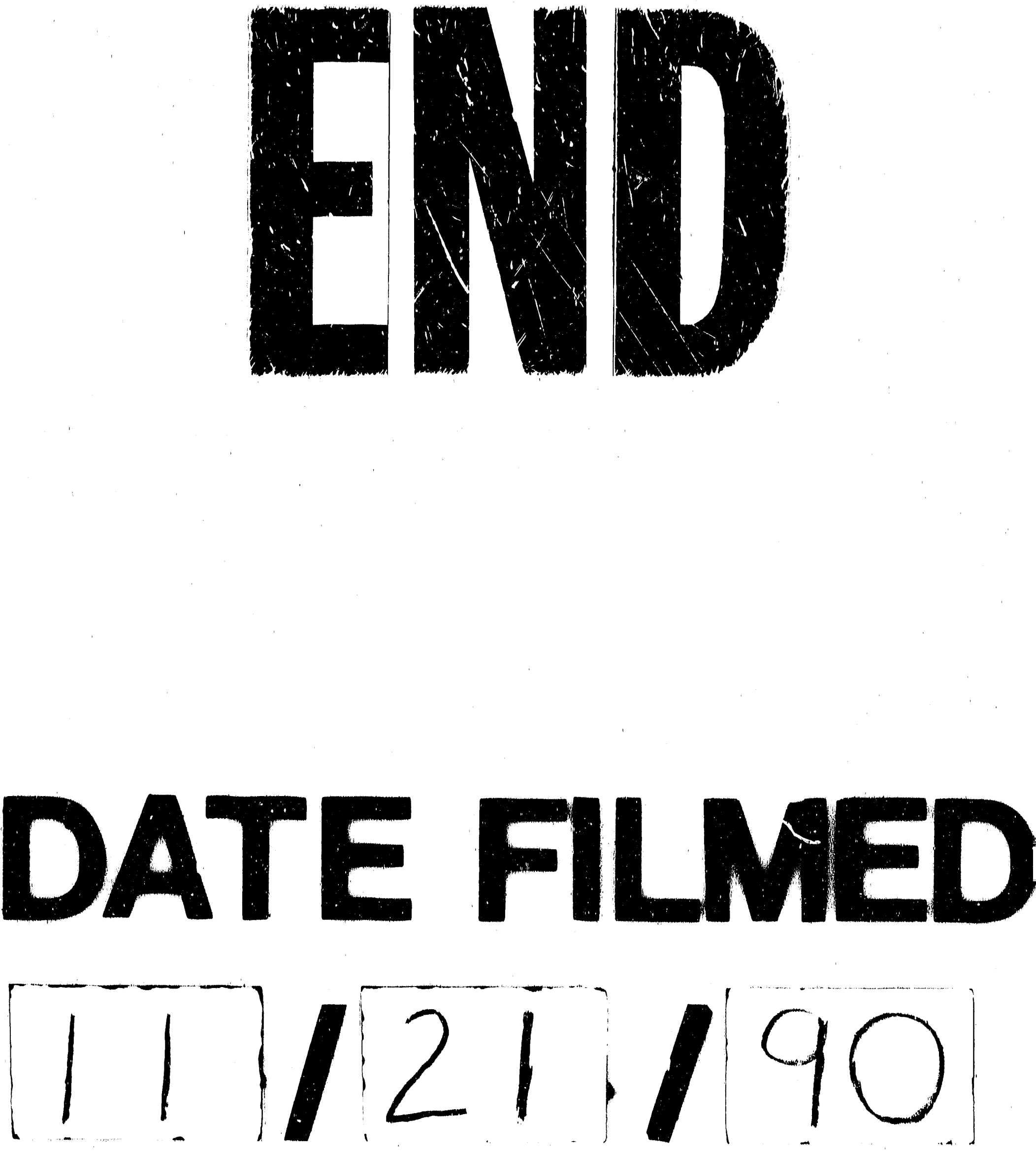
